\title{
Global Analysis of the Zinc Homeostasis Network in Pseudomonas aeruginosa and Its Gene Expression Dynamics
}

\section{OPEN ACCESS}

Edited by:

Haike Antelmann,

Freie Universität Berlin, Germany

Reviewed by:

Christopher Rensing,

Fujian Agriculture and Forestry

University, China

Ankita Sachla,

Cornell University, United States

David P. Giedroc,

Indiana University Bloomington,

United States

Jeffrey Michael Boyd,

Rutgers, The State University

of New Jersey, United States

${ }^{*}$ Correspondence:

Karl Perron

karl.perron@unige.ch

Specialty section:

This article was submitted to Microbial Physiology and Metabolism,

a section of the journal

Frontiers in Microbiology

Received: 12 July 2021 Accepted: 24 August 2021

Published: 08 October 2021

Citation:

Ducret $V$, Abdou M, Goncalves Milho C, Leoni S, Martin--Pelaud O, Sandoz A, Segovia Campos I,

Tercier-Waeber M-L, Valentini $M$ and

Perron K (2021) Global Analysis of the Zinc Homeostasis Network in Pseudomonas aeruginosa and lts

Gene Expression Dynamics.

Front. Microbiol. 12:739988.

doi: 10.3389/fmicb.2021.739988

\author{
Verena Ducret ${ }^{1}$, Melina Abdou' ${ }^{2}$, Catarina Goncalves Milho', Sara Leoni', \\ Oriane Martin--Pelaud ${ }^{1}$, Antoine Sandoz', Inés Segovia Campos ${ }^{1,3}$, \\ Mary-Lou Tercier-Waeber ${ }^{2}$, Martina Valentini ${ }^{4}$ and Karl Perron ${ }^{1,5 *}$
}

${ }^{1}$ Microbiology Unit, Department of Botany and Plant Biology, University of Geneva, Geneva, Switzerland, ${ }^{2}$ Department of Inorganic and Analytical Chemistry, University of Geneva, Geneva, Switzerland, ${ }^{3}$ Department of Earth Sciences, University of Geneva, Geneva, Switzerland, ${ }^{4}$ Department of Microbiology and Molecular Medicine, CMU, Faculty of Medicine, University of Geneva, Geneva, Switzerland, ${ }^{5}$ Institute of Pharmaceutical Sciences of Western Switzerland, University of Geneva, Geneva, Switzerland

Zinc is one of the most important trace elements for life and its deficiency, like its excess, can be fatal. In the bacterial opportunistic pathogen Pseudomonas aeruginosa, Zn homeostasis is not only required for survival, but also for virulence and antibiotic resistance. Thus, the bacterium possesses multiple $\mathrm{Zn}$ import/export/storage systems. In this work, we determine the expression dynamics of the entire $P$. aeruginosa $Z \mathrm{n}$ homeostasis network at both transcript and protein levels. Precisely, we followed the switch from a $Z n$-deficient environment, mimicking the initial immune strategy to counteract bacterial infections, to a Zn-rich environment, representing the phagocyte metal boost used to eliminate an engulfed pathogen. Thanks to the use of the NanoString technology, we timed the global silencing of $\mathrm{Zn}$ import systems and the orchestrated induction of Zn export systems. We show that the induction of Zn export systems is hierarchically organized as a function of their impact on $\mathrm{Zn}$ homeostasis. Moreover, we identify PA2807 as a novel $Z n$ resistance component in $P$. aeruginosa and highlight new regulatory links among Zn-homeostasis systems. Altogether, this work unveils a sophisticated and adaptive homeostasis network, which complexity is key in determining a pathogen spread in the environment and during host-colonization.

Keywords: zinc, homeostasis, NanoString, carbapenem, Pseudomonas aeruginosa

\section{INTRODUCTION}

Zinc $(\mathrm{Zn})$, commonly found as the divalent cation $\mathrm{Zn}^{2+}$, is a trace element primarily involved as a cofactor of many enzymes and therefore essential for life. It is considered as the second most important trace metal after iron (Fe) (Blencowe and Morby, 2003). In prokaryotes, $\mathrm{Zn}$ is principally found bound to proteins (approximately $6 \%$ of the proteome) and the free cellular fraction is kept at a concentration as low as femtomolar (Outten and O'Halloran, 2001). In excess, this metal becomes toxic, especially by competing with other trace elements, giving rise to protein mismetallization (Foster et al., 2014). The equilibrium of cellular Zn concentration is therefore tightly regulated and numerous systems involved in $\mathrm{Zn}$ homeostasis (and that of other divalent cations) are welldescribed in several bacteria (Chandrangsu et al., 2017). 
The toxic properties of $\mathrm{Zn}$ are widely exploited in the context of infection control. Upon bacterial invasion, one of the host defense mechanisms is the sequestration of essential metal ions, in particular $\mathrm{Fe}, \mathrm{Zn}$, and manganese $(\mathrm{Mn})$, by proteins and molecules, leading to so called "nutritional immunity" (KehlFie and Skaar, 2010; Capdevila et al., 2016; Lonergan and Skaar, 2019). Conversely, during phagocytosis, toxic concentrations of $\mathrm{Zn}$ and copper $(\mathrm{Cu})$ are delivered into the phagolysosome, participating in the destruction of the pathogen (Stafford et al., 2013; Gao et al., 2018). Thus, to successfully infect, microorganisms not only must adapt to environments of $\mathrm{Zn}$ deprivation or excess, but also rapidly alternate between these two extreme conditions. The opportunistic Gram-negative pathogen Pseudomonas aeruginosa is an ubiquitous and versatile bacterium that possesses several systems for $\mathrm{Zn}$ homeostasis (Figure 1A). $P$. aeruginosa is responsible for a wide array of severe infections, particularly in cystic fibrosis and immunocompromised patients (Kerr and Snelling, 2009), and Zn homeostasis systems are highly relevant to its pathogenicity (Gonzalez et al., 2019). Notably, they modulate virulence by acting on quorum sensing (Dieppois et al., 2012) as well as antibiotic resistance by repressing the expression of the route of entry for carbapenem antibiotics (Perron et al., 2004).

Numerous systems are involved in the import of $\mathrm{Zn}$ into P. aeruginosa (Pederick et al., 2015). At first, the TonB-dependent receptors ZnuD and PA2911 interact with its energizing TonBExbBD protein complex to translocate extracellular $\mathrm{Zn}$ into the periplasmic space (Gonzalez et al., 2019). Subsequently, the metal crosses the cytoplasmic membrane via either the P-type ATPase $\mathrm{HmtA}$ or via an ATP-binding cassette $(\mathrm{ABC})$ transporter such as $\mathrm{ZnuABC}$, the most common $\mathrm{Zn}$ uptake pathway in bacteria (Pederick et al., 2015). Revealed for the first time in Escherichia coli, this transporter consists of the solute-binding protein (SBP) $\mathrm{ZnuA}$, which scavenges $\mathrm{Zn}$ in the periplasm with a high affinity and brings it to the inner membrane permease ZnuB. The energy required for this transport is provided by the cytoplasmic ATPase ZnuC (Patzer and Hantke, 1998).

Two additional $\mathrm{ABC}$ transporters have been described in P. aeruginosa: PA4063-PA4066 and PA2912-PA2914 (Pederick et al., 2015). Although these transporters have been shown to be overexpressed under conditions of $\mathrm{Zn}$ limitation, they remain poorly characterized and their exact contribution to $\mathrm{Zn}$ uptake remains to be elucidated.

The ZrmABCD system has recently been designated as a new $\mathrm{Zn}$ acquisition system, involving a nicotianaminerelated zincophore called pseudopaline by similarity to the Staphylococcus aureus staphylopine (Lhospice et al., 2017; Mastropasqua et al., 2017). The molecule is synthetized by the $\mathrm{ZrmB}$ and ZrmC cytoplasmic enzymes and then released outside the cell by the EamA-like transporter ZrmD. Internalization of the $\mathrm{Zn}$-pseudopaline complex is mediated by the TonBdependent receptor $\mathrm{ZrmA}$, in a siderophore-like manner (McFarlane and Lamb, 2017). Though many gaps remain to be filled at the mechanical level, the importance of this system under conditions of $\mathrm{Zn}$ limitation and its involvement in bacterial pathogenicity appear evident, especially in a cystic fibrosis context (Hermansen et al., 2018).
A considerable reservoir of $\mathrm{Zn}$ is represented by ribosomal proteins. Indeed, during nutrient deprivation, $P$. aeruginosa copes with metal deficiency by expressing additional ribosomal paralogous proteins, annotated as $\mathrm{C}-$, which have lost their Zn finger domain (Haas et al., 2009; Gonzalez et al., 2019). A release of $\mathrm{Zn}$ probably results from this exchange phenomenon, that can be used by other proteins such as DNA polymerase, primase, etc. The $P$. aeruginosa PA3600PA3601 operon encodes two C- paralogs, RpmE2 and RpmJ2, able to substitute in place and in function the ribosomal proteins $\mathrm{RpmE}$ and $\mathrm{RpmJ}$, respectively. Recent data from E. coli have shown that RpmE2 and RpmJ2 are of comparable efficiency to their Zn-ribbon paralogs (Ueta et al., 2020). Such a strategy is also observed with the global transcription regulator DksA, involved in the stringent response. Under Zn-scarce conditions, the alternative protein DksA2, devoid of a $\mathrm{Zn}$ finger domain, is induced and takes over the functional relay from its paralog DksA (Blaby-Haas et al., 2011; Furman et al., 2013). The $d k s A 2$ gene is found in a Zn-regulated cluster composed of approximately 10 genes including two encoding C- paralog enzymes, pyrC2 and folE2 (Pederick et al., 2015).

Zinc uptake and storage systems are regulated by the onecomponent regulator $\mathrm{Zn}$ uptake regulator (Zur) protein, that belongs to the ferric uptake regulatory (FUR) protein family. Zur senses the cytoplasmic concentration of the metal and its regulatory function is directly related to its ability to reversibly bind Zn (Ellison et al., 2013; Gonzalez et al., 2019). Under conditions of $\mathrm{Zn}$ sufficiency or excess, the regulator is found in a dimeric form containing four $\mathrm{Zn}$ atoms (Zur2Zn4 conformation), which promotes DNA binding and ensures the repression of target genes by preventing RNA polymerase from initiating transcription. In $P$. aeruginosa, nine Zur binding sites were predicted, characterized by a 17 -nucleotide palindromic motif overlapping the -10 of the promoter region (Pederick et al., 2015).

Pseudomonas aeruginosa has the ability to counter high toxic concentrations of $\mathrm{Zn}$. Three families of export systems have been described in this bacterium, including the CzcCBA efflux pump, a homolog of the system found in the metalresistant bacterium Cupriavidus metallidurans (Nies et al., 1989). CzcCBA belongs to the Resistance-Nodulation-Division (RND) group of the Heavy Metal Efflux (HME) family, capable of expelling excess $\mathrm{Zn}$, cadmium (Cd) and cobalt (Co) from the cytoplasmic or periplasmic compartments directly outside the cell (Goldberg et al., 1999). This pump is regulated by the CzcRS two-component system (TCS), where CzcS is the transmembrane sensor and CzcR is the response regulator. CzcS detects and becomes active under conditions of excess periplasmic $\mathrm{Zn}$ or Cd. It then activates CzcR by phosphorylation, which in turn acts as a transcriptional activator of the efflux system, ensuring detoxification of the cell. Additionally, CzcRS TCS has been shown to activate its own transcription, promoting a positive regulation loop, but also to directly repress the OprD porin, the route of carbapenem entry, thus rendering the bacterium resistant to these antibiotics (Perron et al., 2004; Dieppois et al., 2012). 
A

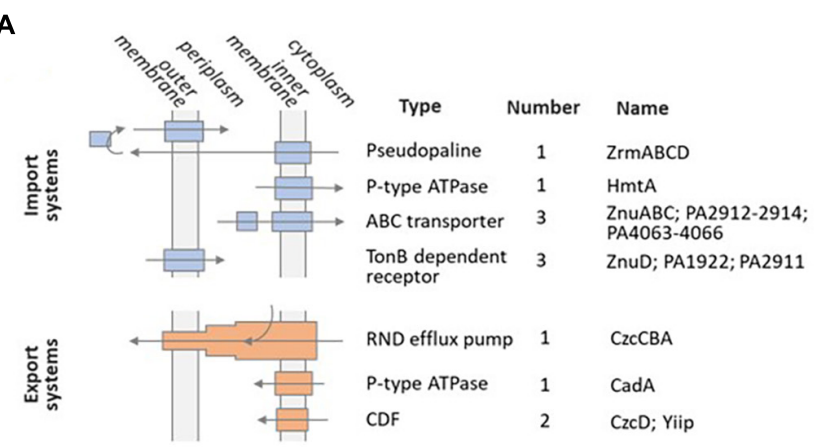

B

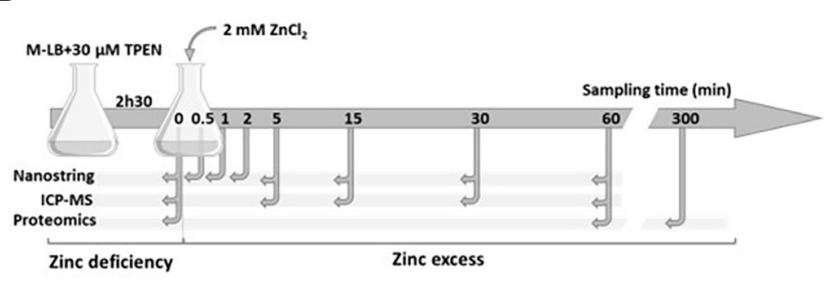

D

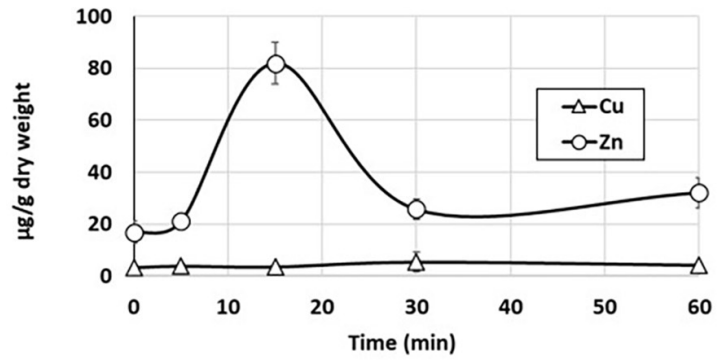

C

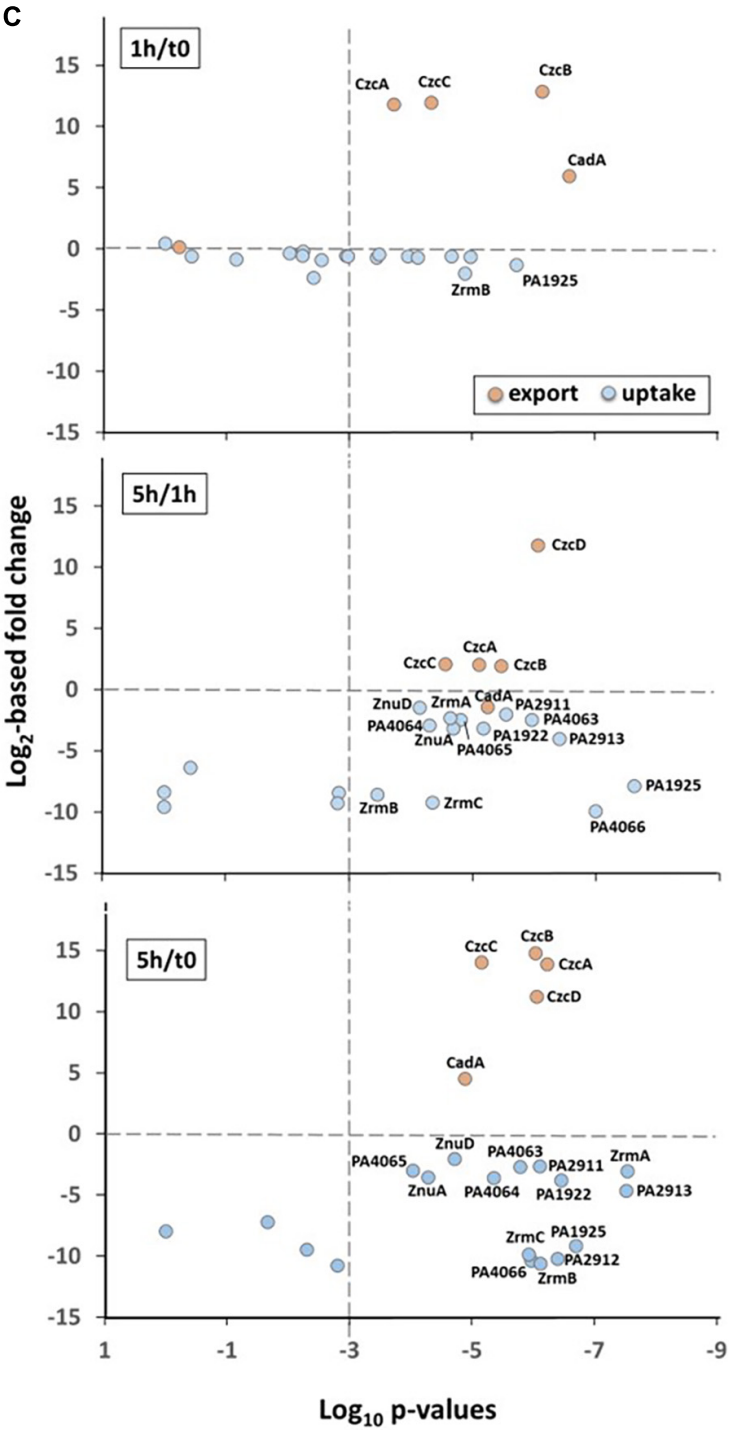

FIGURE 1 | Dynamics of Zn homeostasis in P. aeruginosa. (A) The four families of Zn import systems (in blue) and the 3 families of $Z n$ export systems (in orange) are represented. Their cellular localization, the number of each representative and their name are indicated. (B) Schematic representation of the experimental setup and the times of sampling. (C) Relative abundance of the zinc transport systems. Graphs represent the correlation plots between the fold change (Log 2 value, $y$ axis) after $1 \mathrm{~h}$ compared to to (upper panel), $5 \mathrm{~h}$ compared to $1 \mathrm{~h}$ (middle panel) or $5 \mathrm{~h}$ compared to to (lower panel) of $\mathrm{Zn}$ treatment, and their corresponding statistical values ( $x$ axis). The $p$-values lower than $10^{-3}$ (to the right of the vertical dotted line) were considered as statistically significant. The average values obtained for to (or $1 \mathrm{~h}$ for the middle panel) correspond to $100 \%$. (D) Changes in intracellular zinc concentration after addition of $2 \mathrm{mM} \mathrm{ZnCl}_{2}$ to the medium. The metal concentrations in $\mu \mathrm{g} / \mathrm{g}$ cells (dry weight) were determined over time in the wild type strain by ICP-MS. The concentration of $\mathrm{Cu}$, as control, is also plotted on the graph.

Moreover, the bacterium possesses two cation diffusion facilitators (CDF), $\mathrm{CzcD}$, and YiiP. These systems act as a homodimer or heterodimer to expel $\mathrm{Zn}$ from the cytoplasm to the periplasm by way of a proton gradient. They also appear to be involved in maintaining membrane integrity, which would explain why mutants deleted for these CDFs are more sensitive to several antibiotics (Salusso and Raimunda, 2017).

A final layer consists of the P-type ATPase CadA, which is also responsible for detoxifying the cytoplasm by expelling $\mathrm{Zn}$ to the periplasm. In $P$. aeruginosa, CadA was first described as a system involved in Cd resistance (Lee et al., 2001). Similar to the E. coli
ZntA, this protein has recently been shown to be essential for $\mathrm{Zn}$ resistance (Ducret et al., 2020). CadA is regulated by CadR that belongs to the MerR family of response regulators. CadR is constitutively expressed and has a high affinity for the cadA promoter in the apo and holo forms. The activity of this regulator is directly linked to its ability to bind $\mathrm{Zn}$ since it plays the dual role of repressor and activator of $c a d A$ transcription, depending on whether it is in conditions of $\mathrm{Zn}$ limitation or excess, respectively (Ducret et al., 2020).

Numerous strategies allowing $\mathrm{Zn}$ homeostasis have been described and characterized in $P$. aeruginosa. All these systems 
serve to ensure the survival of the bacterium in environments that are limited or contaminated with $\mathrm{Zn}$ and, interestingly, make the link between metallostasis, virulence and antibiotic resistance. Knowledge of how these systems interact with each other, however, is scarce.

Our lab previously highlighted a dynamic in the expression of $Z n$ export systems in $P$. aeruginosa. Indeed, we had shown that the P-type ATPase CadA was not only the first line of protection against a boost in $\mathrm{Zn}$, but also facilitated the induction of the major export system, the CzcCBA efflux pump (Ducret et al., 2020). These results support the hypothesis that the different systems involved in $\mathrm{Zn}$ resistance are not redundant, but follow a precise strategic plan, guaranteeing a rapid adaptation of the cell to variations in $\mathrm{Zn}$ concentrations.

The purpose of this study was to follow up on the "strategic plan" hypothesis and assess the dynamics of all the systems involved in $\mathrm{Zn}$ homeostasis (import/export/storage) when the bacterium transitions from starvation to surfeit, as it happens during an infection. To achieve this aim, we made use of the NanoString technology, which allows the direct counting of several mRNAs simultaneously by using digital bar-coded probe pairs (Geiss et al., 2008). We could therefore quantify transcripts of all $\mathrm{Zn}$ homeostasis systems, rather than following a single element of the system, and follow their dynamics over time. While we clearly observed a global import systems repression, a hierarchical induction of the export systems appeared. An additional novel partner of the $\mathrm{Zn}$ resistance, PA2807, a CzcE-like protein, was also discovered and characterized. Finally, the rapid induction of carbapenem resistance via OprD porin repression in the presence of $\mathrm{Zn}$ was precisely analyzed at the transcriptomic and proteomic levels.

\section{RESULTS}

In order to monitor the dynamics of $\mathrm{Zn}$ transport systems when $P$. aeruginosa switches from a situation of $\mathrm{Zn}$ starvation to $\mathrm{Zn}$ excess, we designed an experimental procedure described in Figure 1B. Briefly, $P$. aeruginosa $\mathrm{PAO} 1$ strain was cultivated at $37^{\circ} \mathrm{C}$ in a Zn-depleted medium (M-LB) containing $30 \mu \mathrm{M}$ TPEN $\left[N, N, N^{\prime}, N^{\prime}\right.$-tetrakis(2-pyridinylmethyl)-1,2-ethanediamine $]$ to chelate all residual $\mathrm{Zn}$ for $2 \mathrm{~h} 30 \mathrm{~min}$ (Ellison et al., 2013). Then, $2 \mathrm{mM} \mathrm{ZnCl}_{2}$ (final concentration) was added to the culture. Previous to $\mathrm{Zn}$ addition (t0) and at different times afterward, cells were sampled for proteomic, transcriptomic, and $\mathrm{Zn}$ content analysis.

At protein levels we observed, as expected, a significant increase of all export systems during the first hour of high $\mathrm{Zn}$ exposure, while surprisingly the level of only two proteins involved in $\mathrm{Zn}$ import, ZrmB and PA1925, decreased more than 50\% (Figure 1C and Supplementary Table 1). Indeed, the large majority of uptake systems significantly dropped only between 1 and $5 \mathrm{~h}$ after $\mathrm{Zn}$ addition. During this time frame, the amount of the CadA P-type ATPase decreased slightly in agreement with our previous observations on its role of early player in case of a sudden $\mathrm{Zn}$ excess (Ducret et al., 2020). The 5 h-period was also marked by the increasing of the $\mathrm{CzcD}$ protein. This
TABLE 1 | List of the twenty-five genes monitored for zinc homeostasis analysis.

\begin{tabular}{|c|c|c|c|}
\hline Pathway & Gene name & Gene ID & Product description \\
\hline \multirow[t]{5}{*}{ Export } & $C Z C A$ & PA2520 & Cation efflux transporter \\
\hline & $C Z C C$ & PA2522 & Outer membrane protein \\
\hline & $\operatorname{cad} A$ & РА3690 & P-type ATPase transporter \\
\hline & $C Z C D$ & PA0397 & Cation diffusion facilitator transporter \\
\hline & yiï & PA3963 & Cation diffusion facilitator transporter \\
\hline \multirow[t]{12}{*}{ Uptake } & $h m t A$ & PA2435 & P-type ATPase transporter \\
\hline & PA1922 & PA1922 & TonB-dependent receptor \\
\hline & PA2911 & PA2911 & TonB-dependent receptor \\
\hline & PA2914 & PA2914 & Permease of $\mathrm{ABC}$ transporter \\
\hline & PA4063 & PA4063 & Solute-binding protein \\
\hline & PA4065 & PA4065 & Permease of $\mathrm{ABC}$ transporter \\
\hline & PA4066 & PA4066 & Solute-binding protein \\
\hline & znuA & PA5498 & Solute-binding protein \\
\hline & znuB & PA5501 & Permease of $\mathrm{ABC}$ transporter \\
\hline & znuD & PA0781 & TonB-dependent receptor \\
\hline & $z r m A$ & PA4837 & TonB-dependent receptor \\
\hline & $z r m D$ & PA4834 & Nicotianamine synthase \\
\hline \multirow[t]{6}{*}{$\mathrm{C}+/ \mathrm{C}-$ paralogs } & $d k s A$ & PA4723 & Supressor protein \\
\hline & dksA2 & PA5536 & Supressor protein \\
\hline & rpmE & PA5049 & Ribosomal protein L31 \\
\hline & rpmE2 & PA3601 & Ribosomal protein L31 \\
\hline & rpmJ & PA4242 & Ribosomal protein L36 \\
\hline & rpmJ2 & PA3600 & Ribosomal protein L36 \\
\hline \multirow[t]{2}{*}{ Others } & PA2807 & PA2807 & Copper binding protein \\
\hline & oprD & PA0958 & Outer membrane porin \\
\hline
\end{tabular}

very late induction took place after the CzcCBA efflux rise and may explain why this CDF was not essential for $\mathrm{Zn}$ resistance (Ducret et al., 2020).

When looking at the intracellular $\mathrm{Zn}$ concentration over time, the values changed from 0.014 to $0.14 \mu \mathrm{M}$ in $15 \mathrm{~min}$, then returned to equilibrium at a concentration of approximately $0.04 \mu \mathrm{M}$ after $60 \mathrm{~min}$ (Figure 1D). It thus appears that the rapid induction of efflux systems prevails over the slow repression of import systems and it is sufficient to counteract the $\mathrm{Zn}$ overflow.

Finally, to decipher early events of regulation of the $\mathrm{Zn}$ homeostasis network, we directly monitored the transcript levels of genes involved in $\mathrm{Zn}$ transport using the NanoString technology (Geiss et al., 2008). Twenty-five oligonucleotide probes targeting mRNAs of the known $\mathrm{Zn}$ import/export/storage systems of $P$. aeruginosa were designed (Table 1). In addition, four probes targeting housekeeping genes were also designed for data normalization (Supplementary Table 2). In case of a system encoded by operon, we selected at least one gene probe to represent the whole transcription unit (e.g., $c z c A$ and $c z c C$ were chosen to monitor the expression of the $c z c C B A$ operon). For this analysis, RNA was extracted at t0 and $30 \mathrm{~s}, 1,2,5,15,30$, and $60 \mathrm{~min}$ (t0.5, t1 , 2, 5, 13, and 60, respectively) after $\mathrm{Zn}$ addition (Figure 1B). The mRNA copy number for each of the target genes was then calculated in each sample, as shown in Supplementary Table 3. 


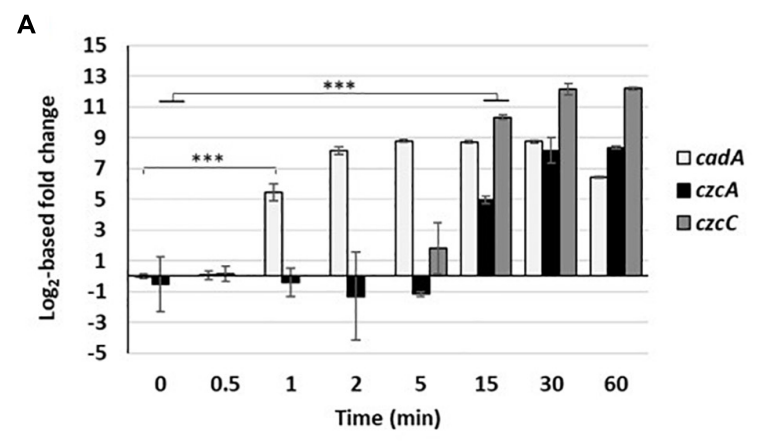

C

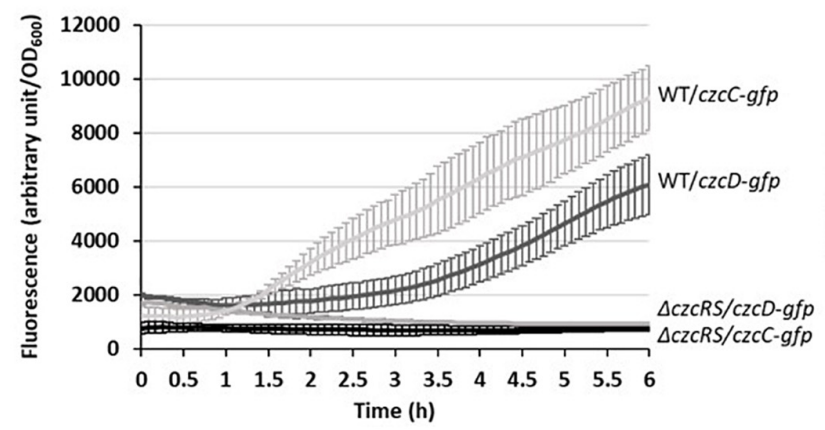

B

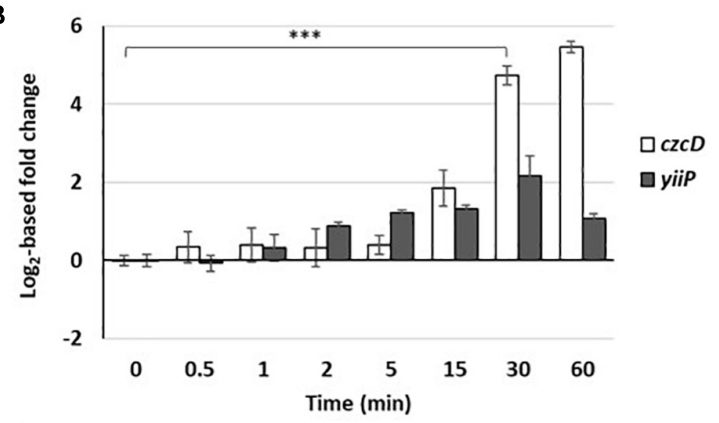

D

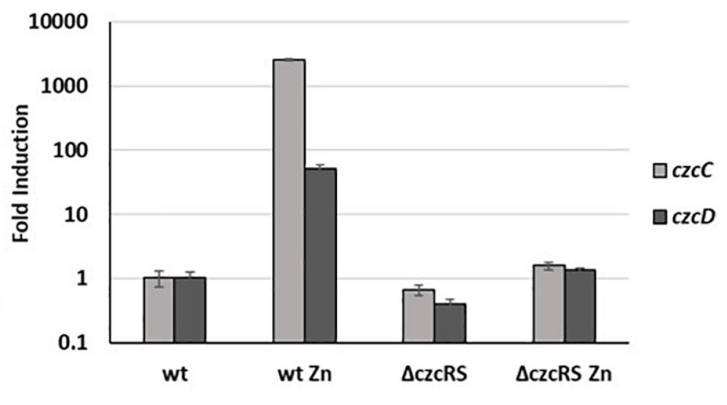

FIGURE 2 | Fold change expression of export systems. (A) cadA (P-type ATPase), czcA and czcC (RND) as well as (B) yiip and czcD (CDF) fold change in the copy number of transcripts measured using the NanoString technology before and after addition of $2 \mathrm{mM} \mathrm{ZnCl}_{2}$ and monitored over the time. Mean values of fold change compared to to (before addition of $\mathrm{Zn}$ ) and standard deviations (error bars) of three independent experiments are represented. Statistical analyses were performed according to the Student's $t$-test and $p$-values are given as follows: $\left.\leq 0.001{ }^{* * *}\right)$. (C) Fluorescence measurement of $p c z c C:: g f p(c z c C)$ and pczcD::gfp (czcD) in the WT strain and the $\triangle c z c R S$ mutant after addition of $2 \mathrm{mM} \mathrm{ZnCl}_{2}$. Values are normalized by optical density $\left(\mathrm{OD}_{600}\right)$. Standard deviations (error bars) of three measurements are indicated. (D) qRT-PCR analysis of $c z c C$ and $c z c D$ mRNAs taken $2 \mathrm{~h}$ after addition of $2 \mathrm{mM} \mathrm{ZnCl}_{2}$. The amount of mRNA is represented relative to time 0 (set to 1), before addition of $\mathrm{ZnCl}_{2}$. Results are normalized using the oprF gene and standard deviations (error bars) of three independent experiments are indicated.

\section{Zn Export Systems}

\section{Dynamics of CadA and CzcCBA Expression}

We recently showed that the two most important systems involved in $\mathrm{Zn}$ resistance in $P$. aeruginosa are the CadA P-Type ATPase and the CzcCBA RND efflux pump (Ducret et al., 2020). These two systems interact together to produce an optimal response to $\mathrm{Zn}$ excess, cadA being rapidly induced, followed by $c z c C B A$ expression. Afterward, $c a d A$ expression decreased while $c z c C B A$ reached its maximal expression (Ducret et al., 2020).

The cadA and $c z c C B A$ expression dynamic is also clearly visible in the NanoString experiment presented here (Figure 2A), thus confirming that this method is suitable for the fine monitoring of gene expression during the low-to-high $\mathrm{Zn}$ concentration transition.

After only $1 \mathrm{~min}$, the amount of cadA mRNA rose to more than 20,000 transcripts, corresponding to a 50-fold induction (Figure 2A). The quantity of mRNA increased up to $5 \mathrm{~min}$, reached a plateau, then decreased after $60 \mathrm{~min}$ (Figure 2A). Interestingly, a basal level of cadA was detected even under Zn-depleted conditions ( $\mathrm{t} 0$ ) with more than 400 transcripts per 50 ng of total RNA (Supplementary Table 3). The levels of $c z c A$ and $c z c C$ transcripts (last and first gene of the $c z c C B A$ operon) reached their maximum after $30 \mathrm{~min}$. After $1 \mathrm{~h}$ in the presence of the metal, a fold induction higher than 330 for $c z c A$ and higher than 4,700 for $c z c C$ was observed. Looking at the number of transcripts (Supplementary Table 3), we noticed that, unlike $c z c C, c z c A$ was already present under conditions of $\mathrm{Zn}$ limitation. Moreover, the number of $c z c A$ mRNA copies detected after $1 \mathrm{~h}$ in the presence of the metal was twice higher than that of $c z c C$. Altogether, this suggested a transcriptional independence of $c z c A$ that could be mediated via an internal transcriptional start site (iTSS) within the $c z c C B A$ operon (Guell et al., 2011). A similar situation has been observed in the $c z c$ operon of C. metallidurans, giving rise to different polycistronic mRNAs, some constitutively expressed and additionally inducible in a CzcR-dependent manner (Grosse et al., 2004).

\section{CzcD Is Part of the CzcRS Regulon}

$\mathrm{CzcD}$ and YiiP are two cation diffusion facilitators (CDF) that export $\mathrm{Zn}$ from the cytosol to the periplasm (Salusso and Raimunda, 2017). Both showed low basal expression even before $\mathrm{Zn}$ addition (Supplementary Table 3). However, the level of yiip mRNA did not increase upon $\mathrm{Zn}$ treatment, while $c z c D$ displayed a 26-fold induction, visible after $30 \mathrm{~min}$ (Figure 2B).

Since $c z c D$ is located on the $c z c$ locus in C. metallidurans (Nies et al., 1989), we wanted to determine whether $c z c D$ is part of the 
CzcRS-mediated regulation. For this purpose, we constructed a transcriptional fusion containing the $c z c D$ promoter controlling a $g f p$ (green fluorescent protein). The expression of the fusion was tested in the wild type (WT) and $\triangle c z c R S$ mutant strain in presence of $2 \mathrm{mM}$ of $\mathrm{ZnCl}_{2}$. Similarly to what is observed for the $c z c C$ promoter (Perron et al., 2004), we could show that $c z c D$ expression depends on the CzcRS TCS since no fluorescence was detected after $\mathrm{Zn}$ induction in the $\triangle c z c R S$ mutant (Figure 2C). This result was also confirmed by qRT-PCR (Figure 2D). The fact that $c z c D$ gene induction is weaker than $c z c C B A$ (Supplementary Table 3) might reflect its secondary role in $\mathrm{Zn}$ resistance (Salusso and Raimunda, 2017; Ducret et al., 2020). Altogether, these results suggest that $c z c D$ is part of the CzcRS regulon.

\section{PA2807, a Novel Link Between $\mathrm{Zn}$ and $\mathrm{Cu}$ Homeostasis}

In C. metallidurans, the $c z c$ element consists of nine genes with a czcNICBADRSE organization (Grosse et al., 2004). We searched for conserved amino acid sequences in $P$. aeruginosa using DIAMOND (Buchfink et al., 2015). No significant CzcI and CzcN homologs were identified. Instead, at low stringency, we found that the PA2807 protein possesses two regions of approximately $40 \%$ sequence identity to C. metallidurans CzcE (Figure 3A). In C. metallidurans, $\mathrm{CzcE}$ is a periplasmic protein that has been shown to bind $\mathrm{Cu}$ but whose expression is also induced by $\mathrm{Zn}$ independently of the CzcDRS regulatory element (Grosse et al., 2004; Zoropogui et al., 2008). Using SignalP 5.0 software (Nielsen, 2017), a putative signal peptide of 48 amino acids that targets PA2807 to the periplasm is predicted with a probability of 0.47 (Figure 3A). To confirm the prediction, we tested the localization of a C-terminal 6His-tagged PA2807 protein expressed in trans in $P$. aeruginosa and we found that it was strongly enriched in the periplasmic fraction (Figure 3B). The amino acid comparison with CzcE from C. metallidurans showed that PA2807 possesses an additional sequence of approximately 70 amino acids between the two conserved regions that contains 7 His residues and may constitute a metal binding site (Figure 3A).

Pseudomonas aeruginosa PA2807 is described as a protein of the cupredoxin family and has been shown to be involved in $\mathrm{Cu}$ resistance (Quintana et al., 2017). No effect on Zn resistance, however, was observed in a disk assay (Teitzel et al., 2006). To assess whether in our experimental settings the PA2807 protein is involved in $\mathrm{Zn}$ and/or $\mathrm{Cu}$ tolerance, we deleted this gene in a $P$. aeruginosa $\mathrm{PAO} 1$ strain and monitored the growth of the $\triangle P A 2807$ mutant in the presence of $3 \mathrm{mM} \mathrm{CuCl}_{2}$ or $5 \mathrm{mM} \mathrm{ZnCl}_{2}$, as compared to the wild type strain (Figure $3 \mathrm{C}$ ). The growth of $\triangle P A 2807$ mutant was clearly delayed, indicating that the protein is indeed contributing to both $\mathrm{Cu}$ and $\mathrm{Zn}$ resistance. The mutant growth deficiency could be complemented by expressing the PA2807 gene on a plasmid (Figure 3C). The involvement of PA2807 in $\mathrm{Cu}$ and $\mathrm{Zn}$ resistance was also confirmed on plate, using serial dilutions spotted on LB plates containing $5 \mathrm{mM}$ $\mathrm{ZnCl}_{2}$ or $3 \mathrm{mM} \mathrm{CuCl}_{2}$ (Supplementary Figure $\mathbf{1}$ ).

To determine whether the transcription of PA2807 could be induced by $\mathrm{Zn}$, we measured its transcript levels via the NanoString analysis. Surprisingly, it turned out to be the most induced gene, almost 10,000 times after $1 \mathrm{~h}$ of induction
(Supplementary Table 3). PA2807 is part of a gene cluster comprised of ptrA (PA2806), PA2807, and queF (PA2808) next to the CopRS TCS (PA2809-PA2810) (Quintana et al., 2017). PtrA is a small periplasmic protein involved in $\mathrm{Cu}$ resistance that has been shown to be also strongly induced in the presence of $\mathrm{Zn}$ (Elsen et al., 2011; Lei et al., 2020). Using semi-quantitative RTPCR, we found that the PA2807 gene is co-transcribed as an operon with $\operatorname{ptr} A$ (Supplementary Figure 2). Interestingly, the ptrA-PA2807 transcript expression is not only induced by CopRS in the presence of $\mathrm{Cu}$, but also in a CzcRS-dependent manner in presence of $\mathrm{Zn}$, as shown by qRT-PCR (Figure 3D).

Altogether, these results demonstrated that the PA2807 protein of $P$. aeruginosa shares several characteristics with C. metallidurans CzcE and appears to be part of the CzcRS regulon in the presence of $\mathrm{Zn}$.

\section{Hierarchy in the Expression of Export Systems}

The induction of the expression of these four $\mathrm{Zn}$ export systems, namely the CadA P-type ATPase, The RND CzcCBA, the two $\mathrm{CDF}$ CzcD and Yiip, along with the newly discovered $\mathrm{CzcE}$ homolog, PA2807, showed a precise chronology of induction, as represented in Supplementary Figure 3. Among all the export systems tested, cadA was the first to be induced $(1 \mathrm{~min}$, early induced gene). The rapid induction is probably due to the CadR regulator already bound to the $\operatorname{cadA}$ promoter region and therefore ready to transcribe $\operatorname{cadA}$ in the event of $\mathrm{Zn}$ excess (Ducret et al., 2020). The $c z c$ regulon containing the $c z c C B A$ efflux pump, $c z c D$ and PA2807 ( $c z c E$-like) induced later (15-30 $\mathrm{min}$, late induced genes), while the gene encoding the CDF yiiP showed no induction under the conditions tested (uninduced gene).

\section{Zn Uptake Systems}

Unlike the protein levels (Figure 1C), the mRNA levels of $\mathrm{Zn}$ import systems were strongly and rapidly repressed once $\mathrm{Zn}$ was added to the medium (Supplementary Figure 3 and Supplementary Table 3). Contrarily to export systems, however, no hierarchy in the regulation was evident and the decrease in the mRNA abundance of all uptake systems was statistically relevant ( $p$-value $\leq 0.001$ ) between 2 and 5 min after $Z n$ addition (Figure 4). One exception to this reduction was observed with the gene encoding the P-type ATPase HmtA, whose mRNA level remained constantly low (Supplementary Table 3). This lack of repression could be due to the fact that this system is mainly involved in Cu import (Lewinson et al., 2009). Finally, among the three ABC transporters involved in Zn uptake, the PA4063-4066 system showed the highest expression (Supplementary Table 3).

\section{C- and C+ Paralog Proteins}

Under conditions of $\mathrm{Zn}$ deficiency, the stringent response regulator DksA is replaced by its DksA2 ortholog, which is devoid of a $\mathrm{Zn}$ finger domain (C- form) (Blaby-Haas et al., 2011). When $\mathrm{Zn}$ reaches sufficient cytoplasmic concentration, $d k s A 2$ transcription is switched off by Zur and DksA takes over its place and function. In agreement with this, a rapid drop in the level of $d k s A 2$ mRNA was observed: after 1 min of metal exposure only half of the number of mRNAs remained (Figure 5A and 
A

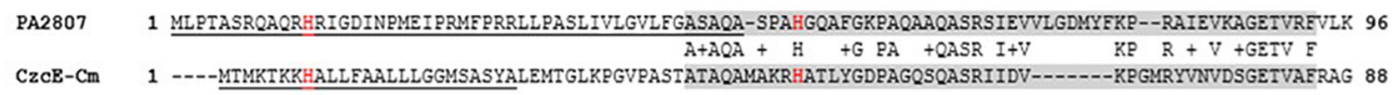

PA2807 97 NEGKLLHEFNLGDAMHAEHQKEMLEMQQSGMLTPTGMASMDHSQMGHGMADMDHGRMMKHDDPNVLVEPGKSAELTWTFTKATRLEEACNIPGHYQAGMVQLTVQP 205 CzcE-Cm 89 - $89-133$

B

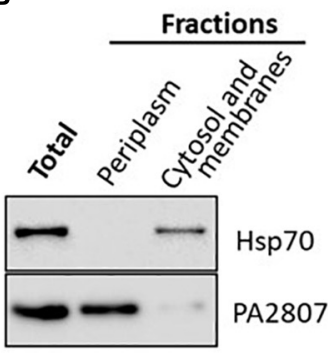

C
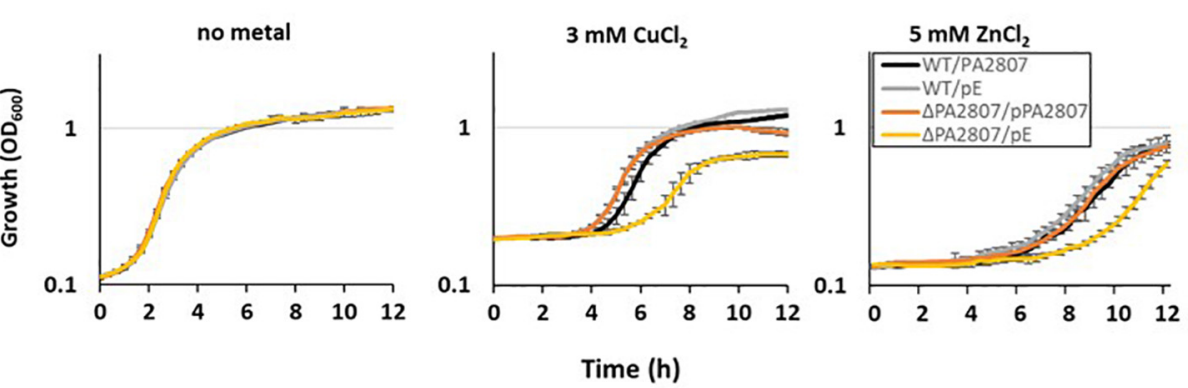

D

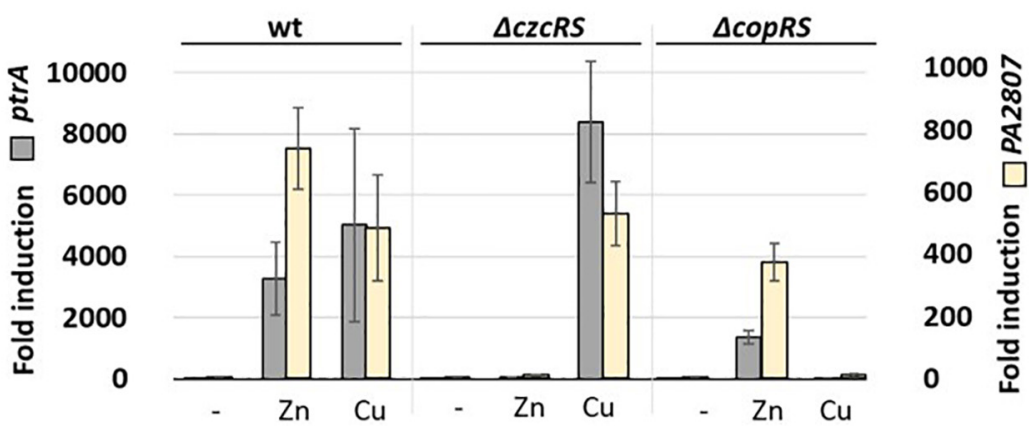

FIGURE 3 | PA2807 encodes a CzcE-like protein. (A) Primary sequence alignment of PA2807 and CzcE from Cupriavidus metallidurans. The transit peptide is underscored and histidine residues are indicated in red. The two boxes of similarity are labeled in gray. (B) Immunoblot analysis of PA2807 localization. A culture of WT P. aeruginosa containing the $6 \mathrm{His}$ tagged version of the PA2807 gene and its promoter on the pME6001 plasmid was induced for $2 \mathrm{~h}$ with $2 \mathrm{mM} \mathrm{CuCl} 2.25 \mu \mathrm{g}$ of total protein, and an equal volume (of $25 \mu \mathrm{g}$ of protein) of periplasmic and cytosolic-membrane fractions was separated on a 4-12\% SDS PAGE. Blots were exposed to anti-6His and anti-Hsp70 (loading and cytosolic control) antibodies. (C) Growth curves of WT P. aeruginosa and the $\triangle P A 2807$ mutant carrying the empty IPTG-inducible pMMB66EH plasmid or the pMMB66EH-PA2807 plasmid. Strains were cultivated in LB medium in the absence or presence of $3 \mathrm{mM}$ CuCl 2 or $5 \mathrm{mM}$ $\mathrm{ZnCl}_{2}$ with $0.1 \mathrm{mM}$ IPTG. (D) Fold induction of ptrA and PA2807 mRNA analyzed using qRT-PCR on RNA extracted after $2 \mathrm{~h}$ of growth in presence of $2 \mathrm{mM} \mathrm{ZnCl}{ }_{2}$ or $2 \mathrm{mM} \mathrm{CuCl}_{2}$ as indicated. Error bars represent the standard deviations of three independent determinations.

Supplementary Table 3). A similar repression profile was shown for the two ribosomal genes rpmE2 and rpmJ2 encoding $\mathrm{Zn}$ deficient orthologs of RpmE and RpmJ, respectively. Unlike their C- substitutes, the mRNA levels of $d k s A, r p m E$, and $r p m J$ remain constant, indicating the simultaneous expression of the three orthologous genes when the environment is depleted of metal. Are both $\mathrm{C}+$ and $\mathrm{C}$ - proteins expressed at the same time or an additional regulatory mechanism occur at the next levels of gene expression? To address this question, we looked at the proteomic analysis focusing on the DksA and RpmE proteins (RpmJ was not detected) and their C- orthologs (Figure 5B and Supplementary Table 2). Intriguingly we observed that, while RpmE2 and DksA2 disappeared rapidly when $\mathrm{Zn}$ is added in excess, the proteins
RpmE and DksA remain present, even in the absence of $\mathrm{Zn}$. A similar regulation is also observed with the two zur-regulated enzymes (Pederick et al., 2015), FolE (GTP cyclohydrolase) and PyrC (dihydroorotase) whose concentrations remain constant in the absence and presence of $\mathrm{Zn}$, while their $\mathrm{C}$ - orthologs, FolE2 and PyrC2 decrease as soon as excess $\mathrm{Zn}$ is added to the medium (Figure 5B).

\section{Zur Affinity}

The transcriptional repression of $\mathrm{Zn}$ import systems as well as the genes encoding $\mathrm{C}$ - proteins are mediated by Zur. A Zur box was predicted for each of the repressed genes or operons (Pederick et al., 2015) and Zur was shown to directly bind to 


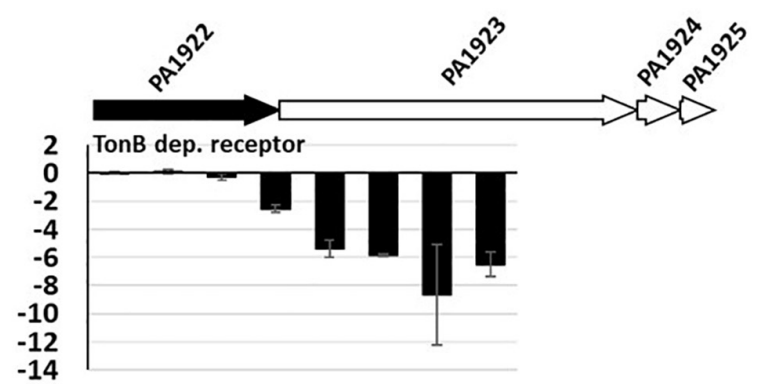

$\begin{array}{llllllll}0 & 0.5 & 1 & 2 & 5 & 15 & 30 & 60\end{array}$
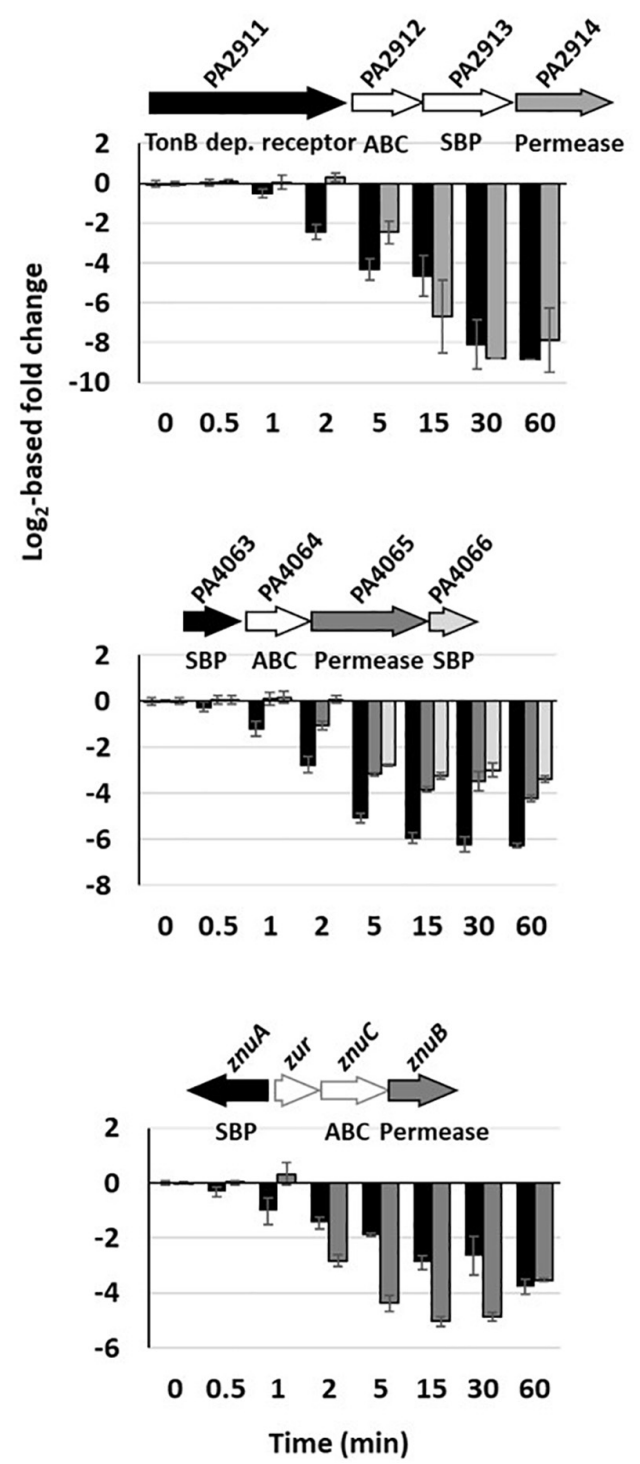
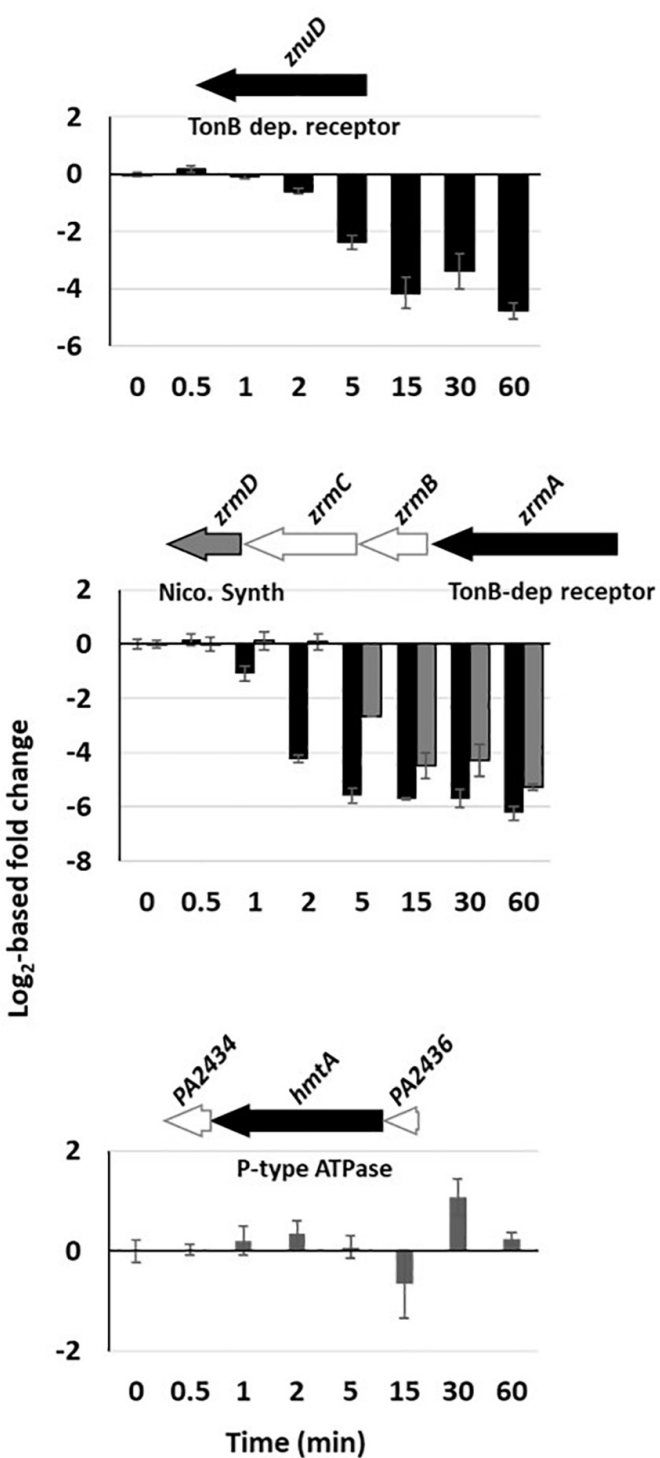

FIGURE 4 | Repression of Zn import systems. The fold change of gene repressions over time of the seven import systems are shown. Fold change of the copy number of transcripts measured using the NanoString technology before and after addition of $2 \mathrm{mM} \mathrm{ZnCl}_{2}$ and monitored over time. Black, dark and clear gray in the histogram correspond to the followed gene in the genomic arrangement represented next to the graph. White arrows represent genes of the system that were not followed during this work. The fold repression gives a $p$-value $\leq 0.001$ between 2 and 5 min after addition of $\mathrm{Zn}$ for all systems, except $h m t A$ for which no repression was detected. 

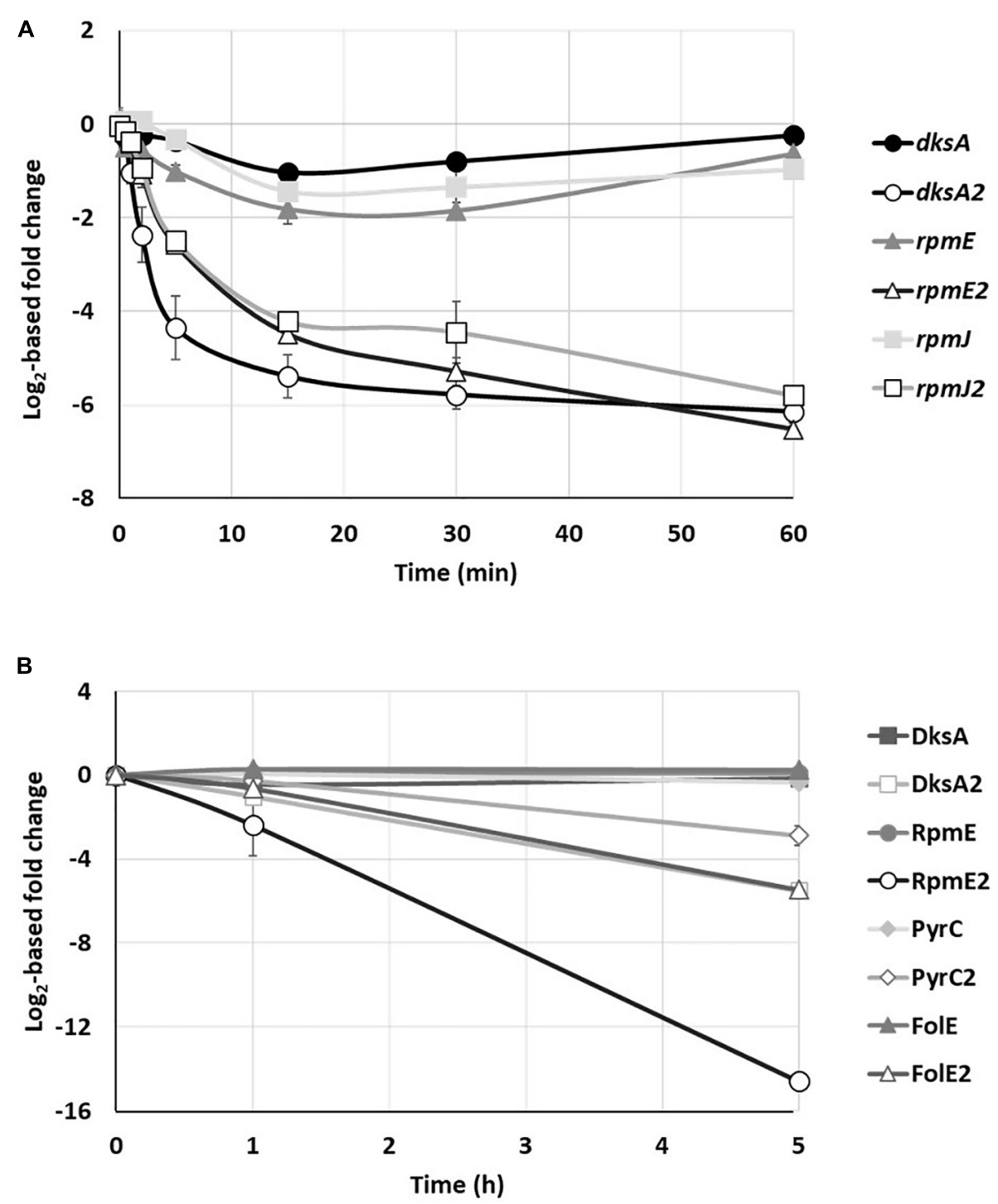

FIGURE 5 | Kinetics of C+/C- protein family. (A) Fold change of rpmE, rpmJ and dksA transcripts and their $\mathrm{C}-$ paralogs over time, after addition of 2 mM ZnCl 2 . (B) Fold changes in the amount of DksA, RpmE, PyrC, and FolE proteins and their C- paralog after addition of $2 \mathrm{mM} \mathrm{ZnCl}_{2}$. Mean values of fold change compared to to (before addition of $\mathrm{Zn}$ ) and standard deviations (error bars) of three independent experiments are represented.

the $z n u A$ and $d k s A 2$ promoters (Blaby-Haas et al., 2011; Ellison et al., 2013). In $P$. aeruginosa this repressor is characterized by $2 \mathrm{Zn}$ binding sites, the structural site located in the C-terminal region and a regulatory $\mathrm{M}$-site (Ellison et al., 2013). The Zur dimer contains $2 \mathrm{Zn}^{2+}$ ions at the structural site and depending on the cytoplasmic $\mathrm{Zn}$ concentration, 0 , 1, or $2 \mathrm{Zn}^{2+}$ ions at the regulatory M-site. In Bacillus subtilis, Zur promoter affinity depends on the amount of $\mathrm{Zn}$ linked to the regulatory site of the protein, allowing a fine cellular response to $\mathrm{Zn}$ by precisely tuning Zur action (Ma et al., 2011).

No clear hierarchy in the repression of Zur regulated genes could be observed with the NanoString experiment after addition of $2 \mathrm{mM} \mathrm{ZnCl} 2$ (Supplementary Figure 3 and Supplementary Table 3 ). We therefore used a more refined analysis to investigate a possible hierarchy in the affinity of the Zur regulator for the various putative Zur targets in $P$. aeruginosa. To this aim, we purified Zur (Supplementary Figure 4) and carried out Electrophoretic Mobility Shift Assay (EMSA) assays, in the absence $(30 \mu \mathrm{M}$ TPEN) or presence of $\mathrm{Zn}(5 \mu \mathrm{M}$ $\mathrm{ZnCl}_{2}$ ) (Figure 6).

All the promoters tested were shifted, including the promoter of the PA2439 gene (first gene of the locus containing hmtA), for which a weak putative Zur binding site had previously been determined in silico (Pederick et al., 2015). Interestingly, two distinct target profiles were emerging from the EMSA analysis. One set of targets exhibited a complete DNA-Zur interaction only in the presence of $\mathrm{Zn}(z n u A, z n u D, P A 4063, P A 2439$, and rpmE2 promoters), while the other showed binding even in the 


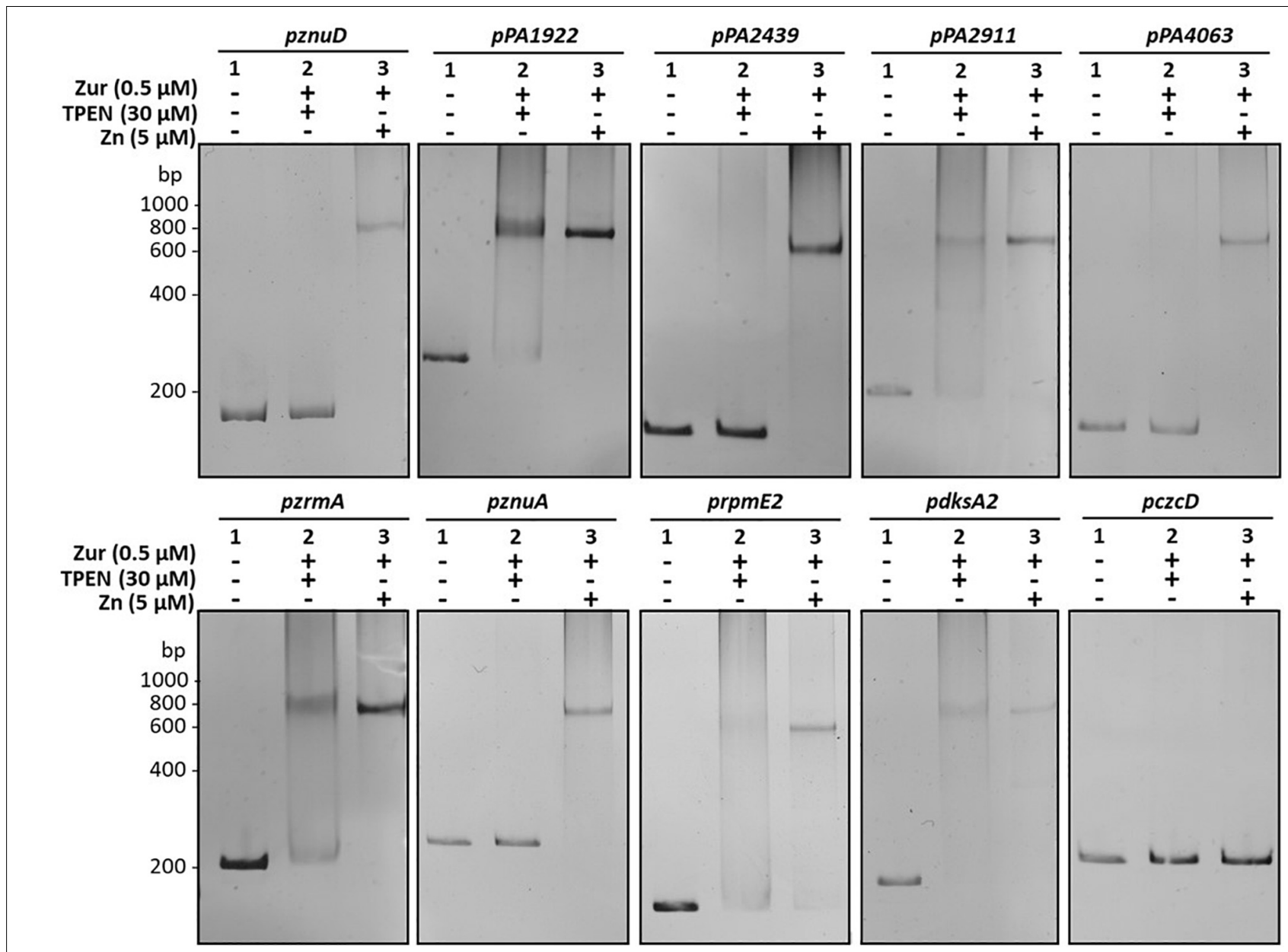

FIGURE 6 | Zur binds to the diverse zur box with different affinities. Electrophoretic mobility shift assays using purified Zur protein and the different target promoters. The $c z c D$ promoter $(p c z c D)$ was used as a negative control. 30 ng of DNA were mixed with (1) 0 nM of Zur, $5 \mu$ M ZnCl $;$; (2) 500 nM Zur and $30 \mu \mathrm{M}$ TPEN (Zn depleted condition); and (3) $500 \mathrm{nM} Z$ ur and $5 \mu \mathrm{M} \mathrm{ZnCl}_{2}$, as indicated. Reactions were loaded on non-denaturing $7.5 \%$ polyacrylamide gels, stained with ethidium bromide and viewed under UV light.

absence of metal. This latter case represented the promoters of the PA1922, PA2911, and zrmA genes, which encode for TonBdependent receptor components (Pederick et al., 2015) and the $d k s A 2$ gene, involved in stringent response under $\mathrm{Zn}$ starvation conditions (Blaby-Haas et al., 2011).

\section{Induction of Carbapenem Resistance}

The response to $\mathrm{Zn}$ in $P$. aeruginosa is linked to carbapenem antibiotic resistance. The route of entry of these antibiotics into the cell is the OprD porin, whose expression is repressed in the presence of $\mathrm{Zn}$ at both transcriptional and post-transcriptional level via the CzcRS TCS and the Hfq RNA chaperone, respectively (Perron et al., 2004; Ducret et al., 2016). Recently, we found that the metal concentrations present in phagolysosomes are sufficient to induce the $\mathrm{Zn}$ response and therefore carbapenem resistance in $P$. aeruginosa (Ducret et al., 2020). We then followed the kinetics of carbapenem resistance induction by quantifying oprD downregulation at the mRNA and protein levels (Figure 7). A delay of 30 min was sufficient to observe a significant drop in
oprD mRNA levels (Figure 7A) and the protein was only slightly present (less than 20\%) after 5 h of induction (Figure 7 B and Supplementary Table 1). This drop was also confirmed at protein levels by a Western blot experiment, where the protein was no longer detectable after $3 \mathrm{~h}$ of metal addition (Figure 7C).

\section{DISCUSSION}

To infect and take advantage of its host, a pathogen must be able to adapt quickly to extreme conditions, including rapid changes in $\mathrm{Zn}$ concentration. $P$. aeruginosa is typically a bacterium armed to counter this kind of situations, as shown by the numerous systems involved in $\mathrm{Zn}$ homeostasis. These systems, together with the ability to express them in a timely fashion, contribute to $P$. aeruginosa ability to infect hosts (Gonzalez et al., 2019). In this study, we carried out a systematic investigation of the expression dynamics of the entire $P$. aeruginosa $\mathrm{Zn}$ homeostasis network when switching from a $\mathrm{Zn}$ depleted environment to a 


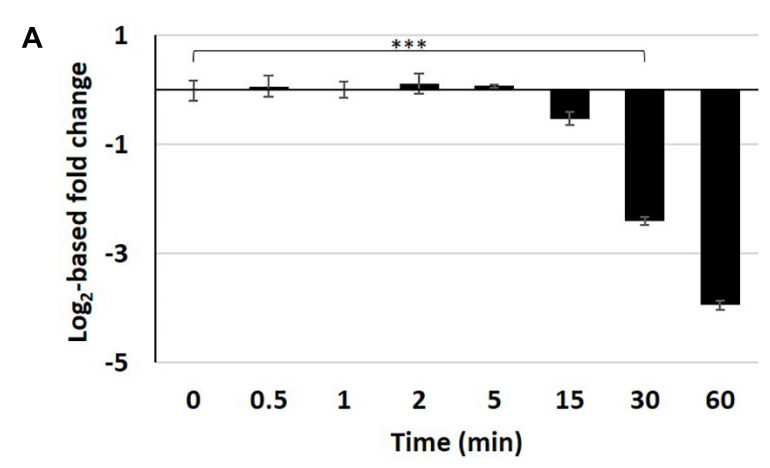

B

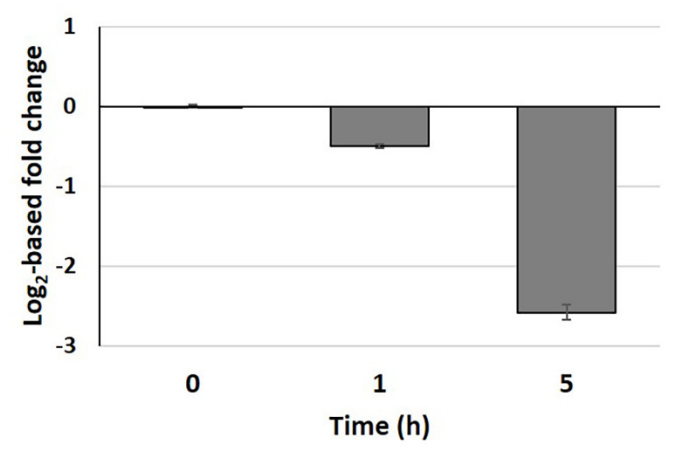

C

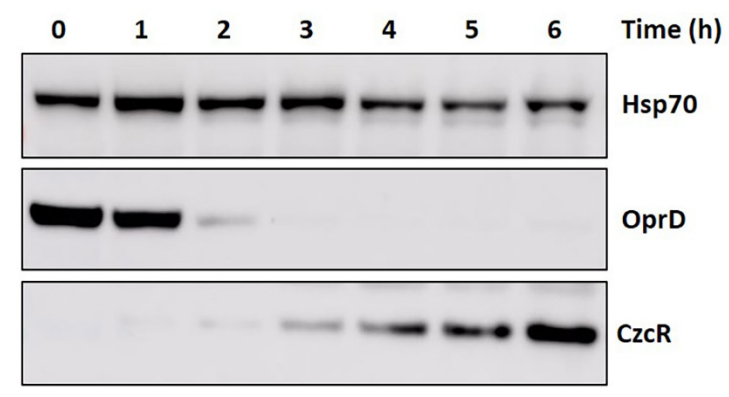

FIGURE 7| Proteomic and transcriptomic kinetics of OprD repression. (A) Fold change in oprD mRNA obtained by the NanoString technique after addition of 2 mM $\mathrm{ZnCl}_{2}$. Mean values of fold change compared to to (before addition of $\mathrm{Zn}$ ) and standard deviations (error bars) of three independent experiments are represented. Statistical analyses were performed according to the Student's $t$-test and $p$-values are given as follows: $\left.\leq 0.001{ }^{(\star \star}\right)$. (B) Fold change in OprD porin compared to t0 (before addition of $\mathrm{Zn}$ ), 1 and $5 \mathrm{~h}$ after addition of $2 \mathrm{mM} \mathrm{Zn}$. (C) Western blot analysis of total protein sampled without $\mathrm{Zn}$ (t0) and after 1-6 $\mathrm{h}$ following the addition of $2 \mathrm{mM} \mathrm{ZnCl}$. Blots were decorated with anti-OprD, anti-CzcR, and anti-Hsp70 as loading control.

Zn excess situation, a transition mimicking what happens during an infectious process (Djoko et al., 2015). Our analysis allowed us to draw a global model of $\mathrm{Zn}$ homeostasis gene expression organization in $P$ aeruginosa, as illustrated in Figure 8.

As a first reaction, we observed a quick induction of cadA expression (after $1 \mathrm{~min}$ ). Presumably, this serves to rapidly evacuate the $\mathrm{Zn}$ excess out of the cytoplasm into the periplasm (Ducret et al., 2020). Downregulation of transcripts for uptake systems is also occurring fast, probably to prevent new $\mathrm{Zn}$ ions from entering the cell. Surprisingly, at the protein level this repression is visible only after $5 \mathrm{~h}$, suggesting a slow turnover of $\mathrm{Zn}$ uptake proteins. Given the importance of $\mathrm{Zn}$ for survival, this might be the result of a "prudential regulatory strategy", to assure a prompt $\mathrm{Zn}$ uptake in case of the metal concentration decreases suddenly.

In a second step, the CzcCBA major efflux system is induced to detoxify all the cellular compartments, thus allowing the bacterium to thrive in an environment highly contaminated with $\mathrm{Zn}$. In agreement with this, a decrease in total cellular $\mathrm{Zn}$ is observed as the expression of $c z c C B A$ increases (Figure 1D). The $\mathrm{CzcD}$ CDF is not an essential component in metal resistance (Ducret et al., 2020), but we show here to be part of the $c z c R S$ 


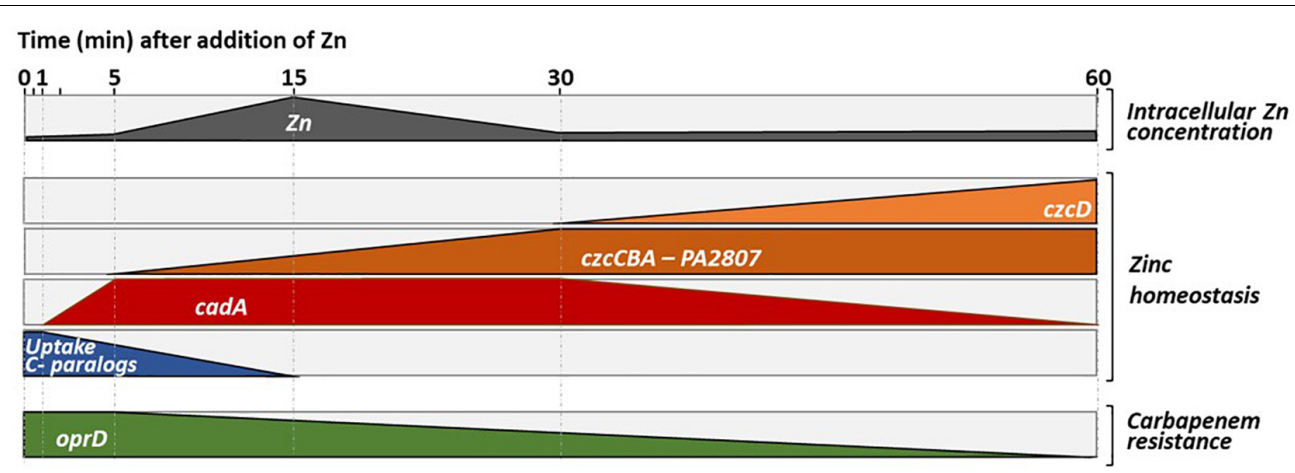

FIGURE 8 | Representation of the dynamics of Zn homeostasis in Pseudomonas aeruginosa. The first block represents the intracellular Zn concentration, which increases when the cells move from a Zn-poor to a Zn-rich environment. An increase in intracellular Zn concentration is observed for up to 15 min, the time it takes for the import systems to be repressed and for the export system to start to eliminate the excess $\mathrm{Zn}$ (see second block and discussion). Later it appears that the ATP-consuming CadA system, is replaced by a less energy-demanding CzcD system that takes over to pump cytoplasmic $\mathrm{Zn}$ into the periplasm. This representation, highlights the repression of the expression of the OprD porin whose abundance is inversely proportional to resistance to the family of carbapenem antibiotics (last block).

regulon (Figure 2) and therefore responding to the periplasmic $\mathrm{Zn}$ concentration. Considering its late induction, $\mathrm{CzcD}$ may contribute to the maintenance of a steady state level of $\mathrm{Zn}$ resistance by continuing to pump $\mathrm{Zn}$ into the periplasm and allowing the $\mathrm{CzcS}$ to remain active while cadA expression decreases. One may consider that the P-type ATPase system CadA, despite being very efficient, uses ATP as an energy source while $\mathrm{CzcD}$ is driven by proton-motive forces and, therefore, might be more profitable for the cell in terms of energy optimization.

The PA2807 gene was previously shown to be induced by the CopRS system in the presence of $\mathrm{Cu}$ (Quintana et al., 2017). Here, we show that it encodes a CzcE-like protein involved in $\mathrm{Zn}$ resistance and also induced by the CzcRS systems in the presence of $\mathrm{Zn}$. The role of this periplasmic protein in $\mathrm{Zn}$ and $\mathrm{Cu}$ resistance requires further investigation, but we could confirm the link between $\mathrm{Zn}$ and $\mathrm{Cu}$ resistance that has already been observed in other bacteria. For instance, in Pseudomonas stutzeri, a common overlapping response to $\mathrm{Cu}$ and $\mathrm{Zn}$ by common regulator DNA binding motifs has been elegantly demonstrated (Garber et al., 2018). In $P$. aeruginosa, the induction of CopRS induces the expression of the CzcRS TCS (Caille et al., 2007). In general, both $\mathrm{Zn}$ and $\mathrm{Cu}$ resistance may allow bacteria to resist to the toxic boost of metals that are discharged into the phagosome of macrophages to kill the pathogens (Botella et al., 2012; Djoko et al., 2015). Shift assays have shown a greater affinity of Zur for promoters controlling the expression of PA1922, PA2911, zrmA, and $d k s A 2$ genes. Interestingly, all these genes are also involved in cobalt (Co) homeostasis, since PA1922 is located within an operon that contains a cobN-like gene (PA1923), PA2911 is cotranscribed with $P A 2914$, a homolog of the cobalamin ABC permease (Pederick et al., 2015) and pseudopaline, involving the zrm system, has been shown to transport metals such as $\mathrm{Zn}, \mathrm{Co}$, $\mathrm{Fe}$, and nickel (Ni) (Zhang et al., 2019). Similarly, $d k s A 2$ is also part of an operon including $P A 5535$, a cobW-like gene, involved in cobalamin biosynthesis. These results might reveal a putative Co-dependent regulatory activity of Zur, which could be linked with vitamin B12 (cobalamin) synthesis (Osman et al., 2021). Our in vitro conditions, by creating a $\mathrm{Zn}$ deficiency using TPEN, could displace the filling of Zur with Co (Osman et al., 2017). Some promoters would thus also appear to react first to a Co boost. The analysis of the sequences of the different Zur boxes did not allow us to highlight any particular signature. The DNA-Zur-Co interaction would deserve further investigation.

In E. coli, each of the 50,000 ribosomes present in exponentially growing cell contains about $3 \mathrm{Zn}^{2+}$ ions, resulting in the recruitment of $75 \%$ of all the intracellular $\mathrm{Zn}$ available (Blaby-Haas et al., 2011). Under conditions of Zn deficiency, the ribosomal proteins RpmE and RpmJ, along with the transcription factor DksA and the two enzymes FolE and PyrC all of which contain $\mathrm{Zn}$-ribbon motifs (and are thus called $\mathrm{C}+$ ) are replaced by their $\mathrm{C}$ - paralog proteins (RpmE2, RpmJ2 DksA2, FolE2, and PyrC2), which lack the key Cys residues and do not require $\mathrm{Zn}$ for their function. This replacement frees $\mathrm{Zn}$, which becomes available for other essential biological tasks (Gabriel and Helmann, 2009). A similar mechanism is found also in B. subtilis, in which the RpmE protein is degraded under $\mathrm{Zn}$ depleted conditions (Akanuma et al., 2006). As expected we found a rapid drop of $\mathrm{C}$ - proteins upon $\mathrm{Zn}$ excess in P. aeruginosa. However, unlike $B$. subtilis, $P$. aeruginosa $\mathrm{C}+$ proteins are constitutively present even in conditions of $\mathrm{Zn}$ deficiency ( $\mathrm{t} 0)$. It is possible that the presence of these proteins reflects a regulatory strategy that guarantees a pool of proteins rapidly functional as soon as $\mathrm{Zn}$ is available.

In summary, this work shows for the first time the dynamics of the components of the $\mathrm{Zn}$ homeostasis network in $P$. aeruginosa. The use of the NanoString technology allowed us to precisely quantify several transcripts simultaneously and to follow their dynamics over time. The complementary proteomic analyses allowed us to observe the final outcome of this regulation and to visualize the $\mathrm{Zn}$ homeostasis systems at steady state (i.e., after $5 \mathrm{~h}$ of growth in presence of $\mathrm{Zn}$ excess). Our findings are important to identify the molecular mechanisms favoring host colonization and infection, as well as to understand the 
environmental signals leading to the insurgence of antibiotic resistance. Specifically, the CzcRS-dependent repression of the oprD porin renders $P$. aeruginosa resistant to carbapenem in presence of $\mathrm{Zn}$ (Perron et al., 2004). According to our data, the OprD protein cannot be detected by western blot after $3 \mathrm{~h}$ of $\mathrm{Zn}$ treatment (Figure $7 \mathrm{C}$ ). We have recently reported OrpD repression during phagocytosis (Ducret et al., 2020). Macrophages, and in general the immune system response, could therefore represent an important underestimated cause of carbapenem phenotypic resistance. Understanding the molecular mechanism favoring the appearance of carbapenem resistance will be thus fundamental to optimize the use of these last resort antibiotics.

\section{MATERIALS AND METHODS}

\section{Bacterial Strains and Culture Media}

The bacterial strains and plasmids used for this study are listed in Supplementary Table 4. Cultures requiring initial $\mathrm{Zn}$ deficiency conditions were carried out in modified Luria-Bertani medium (AppliChem) supplemented with $30 \mu \mathrm{M}$ of $N, N, N^{\prime}, N^{\prime}$ tetrakis(2-pyridinylmethyl)-1,2-ethanediamine (TPEN, Biotum), as described previously (Ducret et al., 2020). Otherwise standard Luria Broth medium (AppliChem) was used. Cultures were incubated at $37^{\circ} \mathrm{C}$ and when required, antibiotics were added to the medium at the following concentrations: $200 \mu \mathrm{g} / \mathrm{mL}$ carbenicillin (Cb, phytotechlab), $50 \mu \mathrm{g} / \mathrm{mL}$ Gentamycin (Gm, AppliChem) and $50 \mu \mathrm{g} / \mathrm{mL}$ tetracycline (Tc, Axxora) for $P$. aeruginosa or $100 \mu \mathrm{g} / \mathrm{mL}$ ampicillin (Ap, AppliChem) and $15 \mu \mathrm{g} / \mathrm{mL}$ Tc or Gm for E. coli.

\section{Genetic Manipulations}

DNA cloning was performed according to standard procedures (Sambrook and Russell, 2001). For Polymerase Chain Reactions, $P$. aeruginosa genomic DNA was used as template and the primers are listed in Supplementary Table 5. Restriction and ligation enzymes (Promega) were employed according to the manufacturer's instructions. Resulting recombinant plasmids were inserted into E. coli $\mathrm{DH} 5 \alpha$ and confirmed by sequencing prior to being transformed into the $P$. aeruginosa wild type or the indicated mutant strains by electroporation (Choi et al., 2006).

Mutants were created according to the following strategy: two fragments flanking either the PA2807 or the copRS TCS locus were amplified by PCR, digested with EcoRI/KpnI for the first insert and $\mathrm{KpnI} / \mathrm{BamHI}$ for the second insert and ligated into the corresponding sites of the pME3087 suicide vector (Voisard et al., 1994). After sequencing verification, recombinant plasmids were transformed into $P$. aeruginosa wild type strain. Merodiploids were resolved as previously mentioned (Ye et al., 1995) and the specific chromosomal deletions were confirmed by PCR amplification and sequencing.

For complementation of the $\triangle P A 2807$ mutant, the full PA2807 gene was amplified by PCR, digested with EcoRI and BamHI restriction enzymes and cloned into the corresponding sites of the IPTG-inducible pMMB66EH vector (Furste et al., 1986). The PA2807 gene was also cloned with a C-terminal $6 \mathrm{His}$ tag into the pME6001 promoter-less vector (Blumer et al., 1999). To this aim, the full gene and its promoter region were obtained by PCR and inserted into the pME6001 plasmid between the BamHI and HindIII restriction sites. For $c z c D:: g f p$ fusion, the $c z c D$ promoter was amplified by PCR, digested with the KpnI and BglII enzymes and then ligated in the corresponding sites of the pBRR1-gfp plasmid (Ouahrani-Bettache et al., 1999).

\section{RNA Extraction}

Total RNA was isolated from the $P$. aeruginosa wild type or mutant strains as formerly explained (Ducret et al., 2020). Briefly, overnight cultures were diluted to an optical density at $600 \mathrm{~nm}$ $\left(\mathrm{OD}_{600}\right)$ of 0.1 and grown for $2 \mathrm{~h} 30 \mathrm{~min}$ in M-LB containing $30 \mu \mathrm{M}$ TPEN. $0.5 \mathrm{~mL}$ of each culture was mixed with $1 \mathrm{~mL}$ of RNA Bacteria Protect Reagent (Qiagen) immediately after $2 \mathrm{mM}$ $\mathrm{ZnCl}_{2}$ induction ( $\mathrm{t} 0$ ) and after several time points as indicated in the different figures. Total RNAs were extracted with an RNeasy mini kit (Qiagen) according to the manufacturer's instructions. $5 \mu \mathrm{g}$ of total RNA were treated with RQ1 RNase-free DNAse (Promega) for $2 \mathrm{~h}$ at $37^{\circ} \mathrm{C}$, followed by phenol/chloroform extraction and ethanol precipitation.

\section{NanoString nCounter Expression Analysis}

mRNA content was analyzed at the iGE3 Genomics Platform (Faculty of Medicine, University of Geneva). $50 \mathrm{ng}$ of total RNA were hybridized with multiplexed NanoString probes listed in Supplementary Table $\mathbf{2}$ and samples were processed according to the published procedure (Geiss et al., 2008). Barcodes were counted for 490 fields of view per sample. Background correction was performed by subtracting the mean +2 standard deviations of the negative controls for each sample. Values $<1$ were set to 1. Positive controls were used as quality assessment: the ratio between the highest and the lowest average of the positive controls among samples was below 3. Counts for target genes were then normalized with the geometric mean of the four reference targets: $f b p, p p i D$, and $r p o D$, selected according to Gifford et al. (2016) and oprF, usually used in the lab to normalize RT-qPCR. The stability of these genes has been verified using the geNorm algorithm (Vandesompele et al., 2002).

\section{Quantitative RT-PCR Analysis}

$500 \mathrm{ng}$ of total RNA was reverse-transcribed using random hexamer primers (Promega) and Improm-II reverse transcriptase (Promega) according to the supplier's instructions. The reverse transcriptase was then heat-inactivated and the resulting cDNAs were diluted tenfold in water. Quantitative PCR was performed in technical duplicates, using SYBR Select Master Mix (Applied biosystem), according to the supplier's instructions. Results were analyzed as previously described (Schmittgen and Livak, 2008) and normalized with the oprF gene.

\section{Semi-Quantitative PCR Analysis}

$500 \mathrm{ng}$ of total RNA from WT $P$. aeruginosa grown in LB, LB supplemented with $2 \mathrm{mM} \mathrm{ZnCl}_{2}$ or with $2 \mathrm{mM} \mathrm{CuCl}_{2}$ was reverse-transcribed as described above and diluted tenfold 
in water. 28 cycles of PCR amplification were performed on the cDNAs and on the corresponding RNA dilution (negative control) as well as on genomic DNA (positive control) using the primers described in Supplementary Table 5. Amplicons were analyzed on a $2 \%$ agarose gel stained with ethidium bromide using a standard procedure.

\section{GFP-Reporter Fusions}

Green fluorescent protein fusion assays were carried out as previously described (Ducret et al., 2020). Precultures of wild type and $\Delta c z c R S$ strains carrying the $p c z c C:: g f p$ or $p c z c D:: g f p$ constructions were diluted to an $\mathrm{OD}_{600}$ of 0.1 , transferred to a 96well black plate (Costar) and grown for $2.5 \mathrm{~h}$ with shaking before

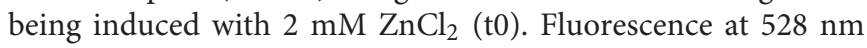
was measured every 15 min using a Microplate reader (Synergy $\mathrm{HT}$, BioTek instrument) and normalized with the $\mathrm{OD}_{600}$ values.

\section{Growth Tests}

Growth experiments were undertaken to investigate the metal susceptibility of the $\triangle P A 2807$ mutant strain compared to the wild type, whether complemented or not with the PA2807 gene. Overnight cultures of the different strains were diluted to an $\mathrm{OD}_{600}$ of 0.05 in LB medium containing $200 \mu \mathrm{g} / \mathrm{mL}$ carbenicillin and $0.1 \mathrm{mM}$ IPTG (isopropyl $\beta$-D-1-thiogalactopyranoside). For growth curve analysis (Figure 3C), cultures were supplemented or not with either $3 \mathrm{mM} \mathrm{CuCl}_{2}$, or $5 \mathrm{mM} \mathrm{ZnCl}_{2}$, transferred to 96 -well plates (Costar) and incubated at $37^{\circ} \mathrm{C}$ with shaking. Absorbance at $600 \mathrm{~nm}$ was measured every 15 min using a Microplate reader (Synergy HT, BioTek instrument). For growth spot assays (Supplementary Figure 1), cultures were grown for $2 \mathrm{~h}$ in LB containing $200 \mu \mathrm{g} / \mathrm{mL}$ carbenicillin and $0.1 \mathrm{mM}$ isopropyl $\beta$-D-1-thiogalactopyranoside (IPTG; Axon Lab), then diluted to $10^{-7} .10 \mu \mathrm{l}$ of each dilution was spotted onto LB plates, supplemented or not with either $3 \mathrm{mM} \mathrm{CuCl}_{2}$ or $5 \mathrm{mM} \mathrm{ZnCl}_{2}$ and incubated at $37^{\circ} \mathrm{C}$ for $24 \mathrm{~h}$.

\section{Western Blot Analyses}

For PA2807 cellular localization, a fractionation procedure was adapted from Elsen et al. (2011). For this purpose, an overnight culture of a WT strain containing the 6His-tagged PA2807 version was diluted to an $\mathrm{OD}_{600}$ of 0.1 in $\mathrm{LB}$ supplemented with $50 \mu \mathrm{g} / \mathrm{mL}$ gentamycin and $2 \mathrm{mM} \mathrm{CuCl}_{2}$. After $5 \mathrm{~h}$ of growth, $1 \mathrm{~mL}$ of cells was harvested and total proteins were solubilized at $2 \mathrm{mg} / \mathrm{mL}$ in 2X SDS-gel sample buffer (Sambrook and Russell, 2001) (an $\mathrm{OD}_{600}$ of 1 gives $0.175 \mathrm{mg} / \mathrm{mL}$ of protein). In parallel, $15 \mathrm{~mL}$ of culture were washed once with TMP buffer $(10 \mathrm{mM}$ Tris-HCl, $200 \mathrm{mM} \mathrm{MgCl}_{2}, 1 \mathrm{mM}$ AEBSF, pH8). Cells were then resuspended in $1 \mathrm{~mL}$ TMP buffer containing $0.5 \mathrm{mg} / \mathrm{mL}$ lysozyme (Fluka) and incubated at room temperature for $30 \mathrm{~min}$ before spinning down. The supernatant corresponds to the periplasmic fraction. The pellet, corresponding to membrane plus cytosolic fractions, was resuspended in the same volume of TMP buffer and sonicated. Both fractions were mixed with an equal volume of $2 \mathrm{X}$ SDS-gel sample buffer.

In order to investigate the kinetics of OprD protein repression over the time, an overnight WT $P$. aeruginosa culture was diluted to an $\mathrm{OD}_{600}$ of 0.05 in M-LB supplemented with $30 \mu \mathrm{M}$ TPEN and incubated for $2 \mathrm{~h} 30 \mathrm{~min}$ at $37^{\circ} \mathrm{C} .1 \mathrm{~mL}$ of culture was collected and centrifuged immediately prior to being induced with $2 \mathrm{mM} \mathrm{ZnCl}_{2}$ and each hour as indicated in Figure 7C. All pellets were solubilized in the appropriate volume of $2 \mathrm{X}$ SDSgel sample buffer to a total protein concentration of $2 \mathrm{mg} / \mathrm{mL}$ (an $\mathrm{OD}_{600}$ of 1 gives $0.175 \mathrm{mg} / \mathrm{mL}$ protein). Proteins were separated on SDS PAGE, using 4-12\% precast gels (Invitrogen). Membrane transfer was performed with an iBlot 2 transfer stack (Invitrogen), according to the manufacturer's instructions. Nitrocellulose membrane was incubated with anti-OprD or antipenta-His and anti-Hsp70 antibodies as previously described (Dieppois et al., 2012). Blots were revealed by chemiluminescence (SuperSignal, Thermo Fisher Scientific), using the Amersham Imager 680 System.

\section{Intracellular Zn Concentration}

The procedure was adapted from D'Orazio et al. (2015). An overnight culture was diluted to an $\mathrm{OD}_{600}$ of 0.1 in M-LB supplemented with $30 \mu \mathrm{M}$ TPEN and incubated $2 \mathrm{~h} 30 \mathrm{~min}$ at $37^{\circ} \mathrm{C}$. $1 \mathrm{~mL}$ of cells were collected and washed once with Phosphate Buffered Saline (PBS, Gibco) containing $1 \mathrm{mM}$ EDTA (Promega). The culture was then induced with $2 \mathrm{mM} \mathrm{ZnCl} 2$ and a $1 \mathrm{~mL}$-sample was collected at 5, 15, 30, and $60 \mathrm{~min}$ after $\mathrm{Zn}$ addition and processed in the same manner, to remove any traces of $\mathrm{Zn}$. Pellets from the whole kinetic sequence were deep-frozen, freeze-dried, and kept in the dark pending analyses. Total dry material was transferred into polypropylene (PP) tubes to perform acid digestion. This was done for $3 \mathrm{~h}$ at $90^{\circ} \mathrm{C}$ placing the PP tubes on Teflon heating blocks after adding $2 \mathrm{~mL}$ hydrochloric acid and $1 \mathrm{~mL}$ nitric acid $(10 \mathrm{M} \mathrm{HCl}$ and $14 \mathrm{M}$ $\mathrm{HNO}_{3}$, respectively, both Suprapur, Merck ${ }^{\circledR}$ ) following protocol adapted from Abdou et al. (2020) for trace metal quantification in biological matrices. Cooled digestates were then diluted in $10 \mathrm{~mL} \mathrm{MilliQ}{ }^{\circledR}$ water and centrifuged at 4,000 rpm for $10 \mathrm{~min}$ $\left(20^{\circ} \mathrm{C}\right)$. The supernatant was stored in acid-cleaned PP tubes. Total $\mathrm{Zn}$ concentrations were quantified by Inductively Coupled Plasma-Mass Spectrometry (ICP-MS, 7900 Agilent $^{\circledR}$ ) in samples diluted 10 fold with $1 \% \mathrm{HNO}_{3}$. Copper $(\mathrm{Cu})$ concentrations were also quantified. Since no Certified Reference Material (CRM) exist for trace metal content in bacteria; other certified biological matrices were analyzed, consisting in plankton material and seaweed $\left(\mathrm{BCR}^{\circledR}-414\right.$ and $\mathrm{CD}^{\circledR} 200$, respectively). Their analyses provided satisfactory results with recoveries for both $\mathrm{Zn}$ and $\mathrm{Cu}$ concentrations $>90 \%$ and precision of $\sim 10 \%(n=6)$. At least triplicate of each condition was analyzed (vertical error bars in the graphics). Detection limits $(3 \times$ blank standard deviation) was estimated to $1.5 \mu \mathrm{g} / \mathrm{g}$ and $0.18 \mu \mathrm{g} / \mathrm{g}$ for $\mathrm{Zn}$ and $\mathrm{Cu}$, respectively, according to an $\mathrm{OD}_{600}$ of 1 resulting in $0.39 \mathrm{~g} \mathrm{~L}^{-1}$ of cell dry weight (Glazyrina et al., 2010).

\section{Zur Expression and Purification}

The zur gene was amplified by PCR, cut with BamHI and EcoRI restriction enzymes and cloned into the pGEX-2T vector. The resulting plasmid was then transformed into the E. coli BL21 strain. Induction and purification were performed as described previously for the CadR protein (Ducret et al., 2020). After removal of the GST tag with the thrombin protease, 
the protein was dialyzed-concentrated against PBS containing $1 \mathrm{mM}$ dithiothreitol (DTT) and 50\% glycerol. Protein purity was checked on SDS-Page (Bio-Rad) stained with Coomassie blue (Supplementary Figure 4) and stored at $-70^{\circ} \mathrm{C}$ until use.

\section{Electrophoretic Mobility Shift Assay (EMSA)}

For the EMSA experiments, all DNA promoters indicated in Figure 6 were obtained by PCR and purified on agarose gel. Binding assays were performed according to the procedure already described (Ducret et al., 2020). Briefly, reactions were performed with a mixture composed of the $5 \mathrm{X} \mathrm{Zn}$-less Binding Buffer ( $50 \mathrm{mM}$ Tris, $200 \mathrm{mM} \mathrm{KCl,} 50 \mathrm{mM} \mathrm{MgCl}_{2}, 5 \mathrm{mM}$ DTT, and $25 \%$ Glycerol), $30 \mathrm{ng}$ of DNA, a Zn excess (5 $\mu \mathrm{M})$ or deficiency $(30 \mu \mathrm{M}$ TPEN) in presence or absence of $500 \mathrm{nM}$ Zur protein and incubated at room temperature for $30 \mathrm{~min}$. Samples were then separated at $4{ }^{\circ} \mathrm{C}$ on a $7.5 \%$ polyacrylamide native gel containing $2.5 \%$ glycerol in Tris Borate Buffer. Binding capacity was analyzed by staining the gel with $0.1 \%$ ethidium bromide and revealed with UV light using a NuGenius instrument.

\section{Proteomic Analyses}

Expression of the DksA and RpmE C-, C+, and OprD proteins was investigated by label-free proteomic analysis. Briefly, an overnight culture of the WT $P$. aeruginosa strain was diluted to an $\mathrm{OD}_{600}$ of 0.1 in M-LB supplemented with $30 \mu \mathrm{M}$ TPEN and incubated for $2 \mathrm{~h} 30 \mathrm{~min}$ at $37^{\circ} \mathrm{C} .1 \mathrm{~mL}$ of culture was collected immediately before ( $\mathrm{t} 0$ ) and after 1 and $5 \mathrm{~h}$ induction with $2 \mathrm{mM} \mathrm{ZnCl}_{2}$. A culture pellet was resuspended in an appropriate volume of $50 \mathrm{mM} \mathrm{NH}_{4} \mathrm{CO}_{3}$ buffer in order to adjust the concentration to $0.5 \mathrm{mg} / \mathrm{mL}$ total proteins. Cells were digested with $0.1 \%$ RapiGest SF Surfactant (Waters) for $30 \mathrm{~min}$ at $60^{\circ} \mathrm{C}$ followed by $5 \mathrm{~min}$ at $100^{\circ} \mathrm{C}$.

Extract contents were analyzed by ElectroSpray IonizationLiquid Chromatography-Mass/Mass Spectrometric (ESI-LCMS/MS) at the Proteomics Core Facility (Faculty of Medicine, University of Geneva). Raw data were processed using Proteome Discoverer 2.3 Software. Label-free quantification was performed using the "Top 3 precursor Intensity" method. Normalization was applied as well as an ANOVA analysis of variance with Bonferroni multiple test correction. A minimum of $10^{5}$, corresponding to the minimum detection value, was fixed for targets with zero values.

\section{Experimental Relevance and Statistical Data}

All experiments were performed, at least, in triplicate. For tables and graph representations, mean values or fold changes are shown in the figures, along with the standard deviations. When indicated, statistical analysis was performed according the Student's $t$-test and significance $p$-value was set to $p \leq 0.001\left(^{* * *}\right)$. For others, the figures show an indicative experiment.

\section{DATA AVAILABILITY STATEMENT}

The data presented in the study are deposited in the Gene Expression Omnibus (GEO) repository, accession number GSE183060.

\section{AUTHOR CONTRIBUTIONS}

$\mathrm{VD}, \mathrm{MV}$, and KP contributed to conception and design of the study, and wrote the manuscript. All authors contributed to formal analysis, investigation, manuscript revision, read, and approved the submitted version.

\section{FUNDING}

This work was supported by funding from the Swiss National Science Foundation (Grant 31003A_179336). MV was supported by an SNSF Ambizione grant (PZ00P3_174063). IS was funded by the Gebert Rüf Stiftung (Basel, Switzerland), Project Microbials GRS071/17. MA was supported by the Portuguese FCT (contract, CEECIND/01777/2018).

\section{ACKNOWLEDGMENTS}

We are thankful for the expertise and advice of Mylene Docquier from the Genomics Platform as well as the Proteomics Core Facility team, both from the Faculty of Medicine of the University of Geneva, Switzerland. We greatly acknowledge Gilbert Pfister and Beat Jermann from the Service de l'Ecologie de l'Eau (SECOE) of the Geneva Canton for providing access to ICP-MS facilities and for their analytical support, as well as Christel Hassler, Isabelle Worms, and Thomas Cherubini for technical support and access to ICP-MS facilities of the UNIGE.

\section{SUPPLEMENTARY MATERIAL}

The Supplementary Material for this article can be found online at: https://www.frontiersin.org/articles/10.3389/fmicb.2021. 739988/full\#supplementary-material

Supplementary Figure 1 | PA2807 and metal resistance. Spot test assay of a serial dilution of the WT and the $\triangle$ PA2807 mutant carrying either an empty pMMB66EH plasmid (pE) or the PA2807 gene cloned under the inducible tac promoter of the pMMB66EH plasmid (pPA2807). After induction with $0.1 \mathrm{mM}$ IPTG $10 \mu \mathrm{L}$ of the various dilutions were spotted onto $\mathrm{LB}, \mathrm{LB}+3 \mathrm{mM} \mathrm{CuCl}_{2}$ or $5 \mathrm{mM} \mathrm{ZnCl}_{2}$, as indicated and incubated for $24 \mathrm{~h}$ at $37^{\circ} \mathrm{C}$.

Supplementary Figure 2 | Co-transcription of the ptrA and PA2807 genes. Semi-quantitative RT-PCR analysis of the three amplicons (indicated in the upper panel) on RNA isolated from $P$. aeruginosa grown in LB, LB containing $2 \mathrm{mM}$ $\mathrm{ZnCl}_{2}$ or $2 \mathrm{mM} \mathrm{CuCl}_{2}$. Primers used for each amplicon are indicated in the Supplementary Table 2. The amplification products were analyzed on a $2 \%$ agarose gel stained with ethidium bromide (lower panel). RNA corresponds to the negative control (without reverse transcriptase) and the Genomic DNA is used as positive control.

Supplementary Figure 3 | Transcription dynamics of genes involved in zinc homeostasis. mRNA counts of export (A) and import (B) systems as determined by NanoString analysis.

Supplementary Figure 4 | Purification of the Zur Protein. $5 \mu \mathrm{g}$ of purified Zur protein were loaded onto a 4-12\% SDS-PAGE and stained with Coomassie Blue. 
Supplementary Table 1 | Proteomic results for systems involved in $\mathrm{Zn}$ homeostasis before and after addition of $2 \mathrm{mM} \mathrm{ZnCl}_{2}$, as indicated. Mean values of three independent experiments and standard deviations are indicated. Undetected proteins are highlighted in gray. Only one value of the triplicate was obtained for FolE.

Supplementary Table 2 | NanoString codeset details.

\section{REFERENCES}

Abdou, M., Gil-Díaz, T., Schäfer, J., Catrouillet, C., Bossy, C., Dutruch, L., et al. (2020). Short-term variations of platinum concentrations in contrasting coastal environments: the role of primary producers. Mar. Chem. 222:103782. doi: 10.1016/j.marchem.2020.103782

Akanuma, G., Nanamiya, H., Natori, Y., Nomura, N., and Kawamura, F. (2006). Liberation of zinc-containing L31 (RpmE) from ribosomes by its paralogous gene product, YtiA, in Bacillus subtilis. J. Bacteriol. 188, 2715-2720. doi: 10. 1128/jb.188.7.2715-2720.2006

Blaby-Haas, C. E., Furman, R., Rodionov, D. A., Artsimovitch, I., and de CrecyLagard, V. (2011). Role of a Zn-independent DksA in Zn homeostasis and stringent response. Mol. Microbiol. 79, 700-715. doi: 10.1111/j.1365-2958.2010. 07475.x

Blencowe, D. K., and Morby, A. P. (2003). Zn(II) metabolism in prokaryotes. FEMS Microbiol. Rev. 27, 291-311. doi: 10.1016/s0168-6445(03)00041-x

Blumer, C., Heeb, S., Pessi, G., and Haas, D. (1999). Global GacA-steered control of cyanide and exoprotease production in Pseudomonas fluorescens involves specific ribosome binding sites. Proc. Natl. Acad. Sci. U.S.A. 96, 14073-14078. doi: 10.1073/pnas.96.24.14073

Botella, H., Stadthagen, G., Lugo-Villarino, G., de Chastellier, C., and Neyrolles, O. (2012). Metallobiology of host-pathogen interactions: an intoxicating new insight. Trends Microbiol. 20, 106-112. doi: 10.1016/j.tim.2012.01.005

Buchfink, B., Xie, C., and Huson, D. H. (2015). Fast and sensitive protein alignment using DIAMOND. Nat. Methods 12, 59-60. doi: 10.1038/nmeth. 3176

Caille, O., Rossier, C., and Perron, K. (2007). A copper-activated two-component system interacts with zinc and imipenem resistance in Pseudomonas aeruginosa. J. Bacteriol. 189, 4561-4568. doi: 10.1128/jb.00095-07

Capdevila, D. A., Wang, J., and Giedroc, D. P. (2016). Bacterial strategies to maintain zinc metallostasis at the host-pathogen interface. J. Biol. Chem. 291, 20858-20868. doi: 10.1074/jbc.r116.742023

Chandrangsu, P., Rensing, C., and Helmann, J. D. (2017). Metal homeostasis and resistance in bacteria. Nat. Rev. Microbiol. 15, 338-350. doi: 10.1038/nrmicro. 2017.15

Choi, K. H., Kumar, A., and Schweizer, H. P. (2006). A 10-min method for preparation of highly electrocompetent Pseudomonas aeruginosa cells: application for DNA fragment transfer between chromosomes and plasmid transformation. J. Microbiol. Methods 64, 391-397. doi: 10.1016/j.mimet.2005. 06.001

Dieppois, G., Ducret, V., Caille, O., and Perron, K. (2012). The transcriptional regulator CzcR modulates antibiotic resistance and quorum sensing in Pseudomonas aeruginosa. PLoS One 7:e38148. doi: 10.1371/journal.pone. 0038148

Djoko, K. Y., Ong, C. L., Walker, M. J., and McEwan, A. G. (2015). The role of copper and zinc toxicity in innate immune defense against bacterial pathogens. J. Biol. Chem. 290, 18954-18961. doi: 10.1074/jbc.r115.647099

D’Orazio, M., Mastropasqua, M. C., Cerasi, M., Pacello, F., Consalvo, A., Chirullo, B., et al. (2015). The capability of Pseudomonas aeruginosa to recruit zinc under conditions of limited metal availability is affected by inactivation of the ZnuABC transporter. Metallomics 7, 1023-1035. doi: 10.1039/c5mt00017c

Ducret, V., Gonzalez, M. R., Leoni, S., Valentini, M., and Perron, K. (2020). The CzcCBA efflux system requires the CadA P-type ATPase for timely expression upon zinc excess in Pseudomonas aeruginosa. Front. Microbiol. 11:911. doi: 10.3389/fmicb.2020.00911

Ducret, V., Gonzalez, M. R., Scrignari, T., and Perron, K. (2016). OprD repression upon metal treatment requires the RNA chaperone $\mathrm{Hfq}$ in Pseudomonas aeruginosa. Genes 7:82. doi: 10.3390/genes7100082
Supplementary Table $3 \mid$ mRNA counts of the target genes involved in zinc homeostasis over time, after addition of $2 \mathrm{mM} \mathrm{ZnCl}$. Mean values and standard deviations of three independent experiments are represented. The software assigned an arbitrary value of 1 to undetected mRNAs (gray boxes).

Supplementary Table 4 | Strains and plasmids used in this study.

Supplementary Table $\mathbf{5}$ | Primers used in this study.

Ellison, M. L., Farrow, J. M. III, Parrish, W., Danell, A. S., and Pesci, E. C. (2013). The transcriptional regulator $\mathrm{Np} 20$ is the zinc uptake regulator in Pseudomonas aeruginosa. PLoS One 8:e75389. doi: 10.1371/journal.pone.0075389

Elsen, S., Ragno, M., and Attree, I. (2011). PtrA is a periplasmic protein involved in Cu tolerance in Pseudomonas aeruginosa. J. Bacteriol. 193, 3376-3378. doi: 10.1128/jb.00159-11

Foster, A. W., Osman, D., and Robinson, N. J. (2014). Metal preferences and metallation. J. Biol. Chem. 289, 28095-28103. doi: 10.1074/jbc.r114.588145

Furman, R., Biswas, T., Danhart, E. M., Foster, M. P., Tsodikov, O. V., and Artsimovitch, I. (2013). DksA2, a zinc-independent structural analog of the transcription factor DksA. FEBS Lett. 587, 614-619. doi: 10.1016/j.febslet.2013. 01.073

Furste, J. P., Pansegrau, W., Frank, R., Blocker, H., Scholz, P., Bagdasarian, M., et al. (1986). Molecular cloning of the plasmid RP4 primase region in a multi-hostrange tacP expression vector. Gene 48, 119-131. doi: 10.1016/0378-1119(86) 90358-6

Gabriel, S. E., and Helmann, J. D. (2009). Contributions of Zur-controlled ribosomal proteins to growth under zinc starvation conditions. J. Bacteriol. 191, 6116-6122. doi: 10.1128/jb.00802-09

Gao, H., Dai, W., Zhao, L., Min, J., and Wang, F. (2018). The role of zinc and zinc homeostasis in macrophage function. J. Immunol. Res. 2018:6872621.

Garber, M. E., Rajeev, L., Kazakov, A. E., Trinh, J., Masuno, D., Thompson, M. G., et al. (2018). Multiple signaling systems target a core set of transition metal homeostasis genes using similar binding motifs. Mol. Microbiol. 107, 704-717. doi: 10.1111/mmi.13909

Geiss, G. K., Bumgarner, R. E., Birditt, B., Dahl, T., Dowidar, N., Dunaway, D. L., et al. (2008). Direct multiplexed measurement of gene expression with color-coded probe pairs. Nat. Biotechnol. 26, 317-325. doi: 10.1038/nbt1385

Gifford, A. H., Willger, S. D., Dolben, E. L., Moulton, L. A., Dorman, D. B., Bean, H., et al. (2016). Use of a multiplex transcript method for analysis of Pseudomonas aeruginosa gene expression profiles in the cystic fibrosis lung. Infect. Immun. 84, 2995-3006. doi: 10.1128/iai.00437-16

Glazyrina, J., Materne, E. M., Dreher, T., Storm, D., Junne, S., Adams, T., et al. (2010). High cell density cultivation and recombinant protein production with Escherichia coli in a rocking-motion-type bioreactor. Microb. Cell Fact. 9:42. doi: 10.1186/1475-2859-9-42

Goldberg, M., Pribyl, T., Juhnke, S., and Nies, D. H. (1999). Energetics and topology of $\mathrm{CzcA}$, a cation/proton antiporter of the resistance-nodulation-cell division protein family. J. Biol. Chem. 274, 26065-26070. doi: 10.1074/jbc.274.37.26065

Gonzalez, M. R., Ducret, V., Leoni, S., and Perron, K. (2019). Pseudomonas aeruginosa zinc homeostasis: key issues for an opportunistic pathogen. Biochim. Biophys. Acta Gene Regul. Mech. 1862, 722-733. doi: 10.1016/j.bbagrm.2018. 01.018

Grosse, C., Anton, A., Hoffmann, T., Franke, S., Schleuder, G., and Nies, D. H. (2004). Identification of a regulatory pathway that controls the heavy-metal resistance system Czc via promoter $\mathrm{czcNp}$ in Ralstonia metallidurans. Arch. Microbiol. 182, 109-118.

Guell, M., Yus, E., Lluch-Senar, M., and Serrano, L. (2011). Bacterial transcriptomics: what is beyond the RNA horiz-ome? Nat. Rev. Microbiol. 9, 658-669.

Haas, C. E., Rodionov, D. A., Kropat, J., Malasarn, D., Merchant, S. S., and de CrecyLagard, V. (2009). A subset of the diverse COG0523 family of putative metal chaperones is linked to zinc homeostasis in all kingdoms of life. BMC Genomics 10:470. doi: 10.1186/1471-2164-10-470

Hermansen, G. M. M., Hansen, M. L., Khademi, S. M. H., and Jelsbak, L. (2018). Intergenic evolution during host adaptation increases expression of the metallophore pseudopaline in Pseudomonas aeruginosa. Microbiology 164, 1038-1047. doi: 10.1099/mic.0.000687 
Kehl-Fie, T. E., and Skaar, E. P. (2010). Nutritional immunity beyond iron: a role for manganese and zinc. Curr. Opin. Chem. Biol. 14, 218-224. doi: 10.1016/j. cbpa.2009.11.008

Kerr, K. G., and Snelling, A. M. (2009). Pseudomonas aeruginosa: a formidable and ever-present adversary. J. Hosp. infect. 73, 338-344. doi: 10.1016/j.jhin.2009.04. 020

Lee, S. W., Glickmann, E., and Cooksey, D. A. (2001). Chromosomal locus for cadmium resistance in Pseudomonas putida consisting of a cadmiumtransporting ATPase and a MerR family response regulator. Appl. Environ. Microbiol. 67, 1437-1444. doi: 10.1128/aem.67.4.1437-1444.2001

Lei, L., Chen, J., Liao, W., and Liu, P. (2020). Determining the different mechanisms used by Pseudomonas species to cope with minimal inhibitory concentrations of zinc via comparative transcriptomic analyses. Front. Microbiol. 11:573857. doi: 10.3389/fmicb.2020.573857

Lewinson, O., Lee, A. T., Rees, D. C., and P-type, A. (2009). ATPase importer that discriminates between essential and toxic transition metals. Proc. Natl. Acad. Sci. U.S.A. 106, 4677-4682. doi: 10.1073/pnas.0900666106

Lhospice, S., Gomez, N. O., Ouerdane, L., Brutesco, C., Ghssein, G., Hajjar, C., et al. (2017). Pseudomonas aeruginosa zinc uptake in chelating environment is primarily mediated by the metallophore pseudopaline. Sci. Rep. 7:17132.

Lonergan, Z. R., and Skaar, E. P. (2019). Nutrient zinc at the host-pathogen interface. Trends Biochem. Sci. 44, 1041-1056. doi: 10.1016/j.tibs.2019.06.010

Ma, Z., Gabriel, S. E., and Helmann, J. D. (2011). Sequential binding and sensing of Zn(II) by Bacillus subtilis Zur. Nucleic Acids Res. 39, 9130-9138. doi: 10.1093/ nar/gkr625

Mastropasqua, M. C., D’Orazio, M., Cerasi, M., Pacello, F., Gismondi, A., Canini, A., et al. (2017). Growth of Pseudomonas aeruginosa in zinc poor environments is promoted by a nicotianamine-related metallophore. Mol. Microbiol. 106, 543-561. doi: $10.1111 / \mathrm{mmi} .13834$

McFarlane, J. S., and Lamb, A. L. (2017). Biosynthesis of an opine metallophore by Pseudomonas aeruginosa. Biochemistry 56, 5967-5971. doi: 10.1021/acs. biochem.7b00804

Nielsen, H. (2017). Predicting secretory proteins with signalP. Methods Mol. Biol. 1611, 59-73. doi: 10.1007/978-1-4939-7015-5_6

Nies, D. H., Nies, A., Chu, L., and Silver, S. (1989). Expression and nucleotide sequence of a plasmid-determined divalent cation efflux system from Alcaligenes eutrophus. Proc. Natl. Acad. Sci. U.S.A. 86, 7351-7355.

Osman, D., Cooke, A., Young, T. R., Deery, E., Robinson, N. J., and Warren, M. J. (2021). The requirement for cobalt in vitamin B12: a paradigm for protein metalation. Biochim. Biophys. Acta. Mol. Cell Res. 1868:118896. doi: 10.1016/ j.bbamcr.2020.118896

Osman, D., Foster, A. W., Chen, J., Svedaite, K., Steed, J. W., Lurie-Luke, E., et al. (2017). Fine control of metal concentrations is necessary for cells to discern zinc from cobalt. Nat. Commun. 8:1884.

Ouahrani-Bettache, S., Porte, F., Teyssier, J., Liautard, J. P., and Kohler, S. (1999). pBBR1-GFP: a broad-host-range vector for prokaryotic promoter studies. Biotechniques 26, 620-622. doi: 10.2144/99264bm05

Outten, C. E., and O'Halloran, T. V. (2001). Femtomolar sensitivity of metalloregulatory proteins controlling zinc homeostasis. Science 292, 24882492. doi: $10.1126 /$ science. 1060331

Patzer, S. I., and Hantke, K. (1998). The ZnuABC high-affinity zinc uptake system and its regulator Zur in Escherichia coli. Mol. Microbiol. 28, 1199-1210. doi: 10.1046/j.1365-2958.1998.00883.x

Pederick, V. G., Eijkelkamp, B. A., Begg, S. L., Ween, M. P., McAllister, L. J., Paton, J. C., et al. (2015). ZnuA and zinc homeostasis in Pseudomonas aeruginosa. Sci. Rep. 5:13139.

Perron, K., Caille, O., Rossier, C., Van Delden, C., Dumas, J. L., and Kohler, T. (2004). CzcR-CzcS, a two-component system involved in heavy metal and carbapenem resistance in Pseudomonas aeruginosa. J. Biol. Chem. 279, 87618768. doi: $10.1074 /$ jbc.m312080200
Quintana, J., Novoa-Aponte, L., and Arguello, J. M. (2017). Copper homeostasis networks in the bacterium Pseudomonas aeruginosa. J. Biol. Chem. 292, 1569115704. doi: 10.1074/jbc.m117.804492

Salusso, A., and Raimunda, D. (2017). Defining the roles of the cation diffusion facilitators in $\mathrm{Fe} 2+/ \mathrm{Zn} 2+$ homeostasis and establishment of their participation in virulence in Pseudomonas aeruginosa. Front. Cell. Infect. Microbiol. 7:84. doi: $10.3389 /$ fcimb.2017.00084

Sambrook, J., and Russell, D. W. (2001). Molecular Cloning: A Laboratory Manual, 3rd Edn. Cold Spring Harbor, NY: Cold Spring Harbor Laboratory Press.

Schmittgen, T. D., and Livak, K. J. (2008). Analyzing real-time PCR data by the comparative C(T) method. Nat. protocol. 3, 1101-1108. doi: 10.1038/nprot. 2008.73

Stafford, S. L., Bokil, N. J., Achard, M. E., Kapetanovic, R., Schembri, M. A., McEwan, A. G., et al. (2013). Metal ions in macrophage antimicrobial pathways: emerging roles for zinc and copper. Biosci. Rep. 33:e00049.

Teitzel, G. M., Geddie, A., De Long, S. K., Kirisits, M. J., Whiteley, M., and Parsek, M. R. (2006). Survival and growth in the presence of elevated copper: transcriptional profiling of copper-stressed Pseudomonas aeruginosa. J. Bacteriol. 188, 7242-7256. doi: 10.1128/jb.00837-06

Ueta, M., Wada, C., and Wada, A. (2020). YkgM and YkgO maintain translation by replacing their paralogs, zinc-binding ribosomal proteins L31 and L36, with identical activities. Genes Cells 25, 562-581.

Vandesompele, J., De Preter, K., Pattyn, F., Poppe, B., Van Roy, N., De Paepe, A., et al. (2002). Accurate normalization of real-time quantitative RT-PCR data by geometric averaging of multiple internal control genes. Genome Biol. 3:RESEARCH0034.

Voisard, C., Bull, C. T., Keel, C., Laville, J., Maurhofer, M., Schnider, U., et al. (1994). "Biocontrol of root diseases by pseudomonas fluorescens CHA0: current concepts and experimental approaches," in Molecular Ecology of Rhizosphere Microorganisms, eds F. O'Gara, D. N. Dowling, and B. Boesten (Weiheim: VCH Verlagsgesellschaft mbh). 67-89. doi: 10.1002/9783527615810.ch6

Ye, R. W., Haas, D., Ka, J. O., Krishnapillai, V., Zimmermann, A., Baird, C., et al. (1995). Anaerobic activation of the entire denitrification pathway in Pseudomonas aeruginosa requires Anr, an analog of Fnr. J. Bacteriol. 177, 3606-3609. doi: 10.1128/jb.177.12.3606-3609.1995

Zhang, J., Zhao, T., Yang, R., Siridechakorn, I., Wang, S., Guo, Q., et al. (2019). De novo synthesis, structural assignment and biological evaluation of pseudopaline, a metallophore produced by Pseudomonas aeruginosa. Chem. Sci. 10, 6635-6641. doi: 10.1039/c9sc01405e

Zoropogui, A., Gambarelli, S., and Coves, J. (2008). CzcE from Cupriavidus metallidurans $\mathrm{CH} 34$ is a copper-binding protein. Biochem. Biophys. Res. Commun. 365, 735-739. doi: 10.1016/j.bbrc.2007.11.030

Conflict of Interest: The authors declare that the research was conducted in the absence of any commercial or financial relationships that could be construed as a potential conflict of interest.

Publisher's Note: All claims expressed in this article are solely those of the authors and do not necessarily represent those of their affiliated organizations, or those of the publisher, the editors and the reviewers. Any product that may be evaluated in this article, or claim that may be made by its manufacturer, is not guaranteed or endorsed by the publisher.

Copyright (c) 2021 Ducret, Abdou, Goncalves Milho, Leoni, Martin--Pelaud, Sandoz, Segovia Campos, Tercier-Waeber, Valentini and Perron. This is an open-access article distributed under the terms of the Creative Commons Attribution License (CC BY). The use, distribution or reproduction in other forums is permitted, provided the original author(s) and the copyright owner(s) are credited and that the original publication in this journal is cited, in accordance with accepted academic practice. No use, distribution or reproduction is permitted which does not comply with these terms. 